\title{
Electrophysiological and Morphological Properties of Rat Basolateral Amygdaloid Neurons in vitro
}

\author{
Mark S. Washburna and Hylan C. Moises \\ Department of Physiology and Neuroscience Program, The University of Michigan, Ann Arbor, Michigan 48109-0622
}

Electrophysiological and morphological properties of neurons in the rat basolateral amygdala (BLA) were assessed using intracellular recordings in brain slice preparations. The vast majority of cells studied were identified as pyramidal cells on the basis of their accommodation response and by a prominent afterhyperpolarization that followed a currentevoked burst of action potentials. The second class of cells consisted of late-firing neurons that were distinguished electrophysiologically by their very negative resting membrane potential $(-82 \mathrm{mV})$ and conspicuous delay in the onset of spike firing in response to depolarizing current injection. The third class of cells, termed fast-firing neurons, possessed many of the features of intrinsic inhibitory interneurons found elsewhere in the brain. These included very brief action potentials $(0.7 \mathrm{msec})$, a relatively depolarized resting membrane potential $(-62 \mathrm{mV})$, and spontaneous firing at a high rate and the absence of spike frequency accommodation.

Intracellular labeling with Lucifer yellow of electrophysiologically identified pyramidal and late-firing cells showed them to have pyramidal to stellate cells bodies and spinecovered dendrites. Although having an overall pyramidallike morphology, late-firing neurons possessed cells bodies and dendritic fields that were smaller than those of pyramidal cells. Lucifer yellow-labeled fast-firing neurons had a nonpyramidal morphology, with somata that were spherical to multipolar in shape and spine-sparse or aspiny dendrites. The morphological features of these cells corresponded closely to those of GABA-containing interneurons that have been described previously in the rat BLA using immunohistochemical techniques (McDonald, 1985b). Thus, it seems likely that activation of fast-firing neurons underlies inhibitory synaptic events that are recorded in the rat BLA.

Our data support the conclusion derived from previous anatomical studies that pyramidal neurons constitute the predominant cell type in the BLA and function as projection neurons in this region of the amygdala. The determination of whether late-firing cells constitute a unique class of projection neurons distinct from pyramidal cells must await the outcome of studies in which the anatomical terminations of this cell type are specified.

Received Jan. 22, 1992; revised May 13, 1992; accepted May 20, 1992.

This work was supported by U.S. Public Health Service Grants DA-03365 and AG 10667 to II.C.M.

Correspondence should be addressed to Dr. Hylan C. Moises, Department of Physiology, The University of Michigan, Ann Arbor, MI 48109-0622.

aPresent address: Department of Neuroscience Pharmacology, Parke-Davis Research Division, Warner-Lambert Company, Ann Arbor, MI 48105.

Copyright (c) 1992 Society for Neuroscience 0270-6474/92/124066-14\$05.00/0
To gain a full understanding of the integrative mechanisms involved in the processing of information within a neural circuit, it is first necessary to characterize fully the properties of its constituent elements (Llinás, 1988). This kind of basic information is critical when the task at hand involves the characterization of the intrinsic organization and cellular interactions in a brain region as complex and poorly understood as the basolateral amygdaloid nucleus (BLA). Light microscopic analyses of Golgi-impregnated neurons in the rat BLA (McDonald, 1982, 1984; Millhouse and DeOlmos, 1983) have described three basic cell types. The first group consists of spiny pyramidal or stellate projection neurons that comprise greater that $95 \%$ of the cells in this nucleus. A second, rarely observed class of neurons is composed of neurogliaform cells (McDonald, 1982, 1984). The third class consists of a heterogeneous population of aspiny or spine-sparse stellate cells with somata averaging $15 \mu \mathrm{m}$ in diameter (McDonald, 1982, 1984; Millhouse and DeOlmos, 1983). Immunohistochemical studies performed with antiserum generated against GABA (McDonald, 1985b) or glutamic acid decarboxylase (Carlsen, 1988) indicate that this third class of cells represents intrinsic GABAergic interneurons. Subsequent immunohistochemical studies have demonstrated that the continuum of cell morphologies represented in the class of aspiny local circuit neurons correspond to separate populations of peptide-containing interneurons, the majority of which colocalize GABA (McDonald, 1985a; McDonald and Pearson, 1989). While anatomical studies have clearly demonstrated that a considerable degree of morphological heterogeneity exists within the rat BLA, to date the only electrophysiological characterizations of neurons in this brain region have been confined to the predominant pyramidal-type neurons (Gean and Shinnick-Gallagher, 1989; Rainine et al., 1991a,b; Washburn and Moises, 1992a,b).

In the present study, conventional intracellular recordings were used to characterize the electrophysiological properties of pyramidal and nonpyramidal cell types in the rat BLA. This was followed with intracellular labeling of cells with the fluorescent dye Lucifer yellow (LY), which allowed for the morphological characterization of physiologically identified neuronal types within the BLA. We have found that cells with physiological properties akin to those of the pyramidal BLA cells described previously (Gcan and Shinnick-Gallagher, 1989; Rainine et al., $1991 \mathrm{a}$; Washburn and Moises, 1992a,b) possessed morphological characteristics that were quite similar to those of pyramidal cells in rat hippocampus and cortex. In addition, this study provides the first electrophysiological characterization of two morphologically distinct classes of nonpyramidal cells that appear to correspond, respectively, to intrinsic GABAergic 
interneurons and a physiologically distinct but chemically unidentified subclass of small pyramidal-like neurons.

A preliminary report of these findings has appeared previously (Washburn and Moises, 1990).

\section{Materials and Methods}

Male Sprague-Dawley rats (Charles River) weighing 150-250 gm were used in this study. Animals were killed by decapitation and their brains quickly removed and placed in ice-cold oxygenated artificial cerebrospinal fluid (ACSF) consisting of (in $\mathrm{mM}$ ) NaCl, $124 ; \mathrm{KCl}, 3.5 ; \mathrm{MgSO}_{4}$, $1.5 ; \mathrm{NaH}_{2} \mathrm{PO}_{4}, 1.0 ; \mathrm{NaHCO}_{3}, 26.2 ;$ glucose, $11.0 ;$ and $\mathrm{CaCl}_{2}, 3.0$. Slices of ventral forebrain containing the amygdala were cut at a thickness of $450 \mu \mathrm{m}$ in the horizontal plane using a Vibroslicer. One slice was transferred immediately to the recording chamber and held submerged between two layers of nylon mesh under continuously flowing ACSF prewarmed to $32^{\circ} \mathrm{C}$. The remaining slices were transferred to an incubation chamber and maintained in oxygenated ACSF at room temperature $\left(23^{\circ} \mathrm{C}\right)$. Slices were allowed to equilibrate for at lcast $1 \mathrm{hr}$ beforc intracellular recordings were attempted.

Conventional intracellular voltage recordings were obtained from cells in the BLA nucleus using glass microelectrodes filled with $2 \mathrm{M}$ potassium acetate ( $\mathrm{pH} \mathrm{7.0)}$ and having resistances of 90-160 M $\Omega$. Recordings were amplified and displayed on an oscilloscope and Gould chart recorder. Signals were also fed to a computer interface (TL-1, Axon Instruments) that digitized the analog waveforms for analysis by a microcomputerbased program (pCLAMP, Axon Instruments).

Only cells with membrane potentials greater than $-55 \mathrm{mV}$ and overshooting action potentials were included in this study. Under our recording conditions, the vast majority of BLA cells were not spontaneously active but cells could be made to fire by passage of direct depolarizing current pulses through the recording electrode using a standard bridgebalance circuit (Axoprobe 1-A, Axon Instruments). Input resistance was determined by passing an incremental series of current pulses $(0.1 \mathrm{nA}$ increments; range, $-0.8 \mathrm{nA}$ to $+0.1 \mathrm{nA} ; 150 \mathrm{msec}$ ) through the recording electrode and measuring the resultant voltage deflections. Current-voltage plots were then constructed by plotting the amplitude of each deflection against the amplitude of the corresponding current pulse. The slope of the line representing a linear regression of these points was taken to be the input resistance. Membrane time constants were calculated for small $(150 \mathrm{msec})$ hyperpolarizing current pulses $(-0.3$ to $-0.2 \mathrm{nA}$ ) using a least-squares fit exponential-fitting program (CLAMPFIT, Axon Instruments).

EPSPs and IPSPs were elicited in BLA neurons by delivering voltage pulses of $0.1 \mathrm{msec}$ duration via a bipolar stimulating electrode placed on the surface of the slice over the external capsule (EC). While the EC could be easily identified visually, we relied on anatomical landmarks in the slice and diagrams of stereotaxically defined sections (Paxinos and Watson, 1982) for guiding placement of the recording electrode in the BLA. Typically, the stimulus intensity delivered was that which evoked an EPSP whose amplitude was just below threshold for generating an action potential when recordings were made at the resting membrane potential. Membrane potential was manually adjusted by intracellular injection of direct current through the recording electrode, and was held at -80 to $-90 \mathrm{mV}$ when characterizing EPSPs elicited by EC stimulation and at near threshold for firing (approximately -60 $\mathrm{mV}$ ) when examining orthodromically evoked IPSPs.

4-Aminopyridine (4-AP; Sigma) was applied to the slice by switching the bath superfusate from normal ACSF to ACSF containing known concentrations of drug. In some experiments, TTX ( $1 \mu \mathrm{M}$; Sigma) was included in the bathing medium to block action potential-dependent neurotransmitter release and to distinguish direct actions of drugs on the neuron under study from possible remote actions.

For intracellular labeling of neurons, electrodes were filled with $4 \%$ LY CH (dilithium salt; Sigma) in $1 \mathrm{M}$ lithium acetate. These electrodes typically had resistances between 120 and $300 \mathrm{M} \Omega$. After characterization of passive and active membrane properties, neurons were dye filled by passing 0.5-1.0 nA hyperpolarizing constant current usually for 5$10 \mathrm{~min}$. Brain slices containing LY-filled cells were fixed overnight in $4 \%$ paraformaldehyde and then stored up to 1 week in Tris-buffered saline solution at $4^{\circ} \mathrm{C}$. Slices were then dehydrated in alcohol and cleared in methyl salicylate. Cells were observed and photographed using a Leitz Orthoplan microscope. Camera lucida drawings were also made of the majority of labeled cells.

\section{Results}

Earlier reports from this (Moises and Washburn, 1990; Washburn and Moises, 1992; Womble and Moises, 1992) and other laboratories (Gean and Shinnick-Gallagher, 1988, 1989; Rainine et al., 1991a,b) have provided detailed descriptions of the properties of pyramidal-type neurons in the rat BLA. In these studies, neurons were characterized as pyramidal cells primarily on the basis of the responses they showed to depolarizing current pulses. In the present study, we were able to characterize two additional cell types in rat BLA as distinct from pyramidal cells on the basis of their current-evoked pattern of discharge. The first type of neuron fired single action potentials at a delayed onset in response to a current-evoked depolarization and will therefore be referred to as late-firing cells. The second class of nonpyramidal cells fired very short-duration action potentials at high frequency immediately upon depolarization and showed no sign of spike frequency accommodation during prolonged depolarizing stimuli. These cells will subsequently be referred to as fast-firing neurons. The electrophysiological properties of all three cell classes of BLA neurons are described below, along with their morphological characteristics as revealed by LY labeling.

\section{Pyramidal-type neurons}

We have recorded from over 689 neurons in the rat BLA that met minimal criteria for health and stability. Approximately 93\% of the intracellular recordings obtained were from cells that displayed a common profile of electrophysiological properties that have served previously to identify such neurons as pyramidal cells (Washburn and Moises, 1992a,b). While the electrophysiological characteristics of pyramidal-type neurons in this report are essentially the same as previously described (see Washburn and Moises, 1992a,b), the properties of a representative sample of these neurons are reiterated here for purposes of comparison with those of the two nonpyramidal cell types. Pyramidal cells had a mean resting membrane potential of -69.5 $\pm 0.7 \mathrm{mV}$ (mean $\pm \mathrm{SEM} ; n=85$ ) and were not spontaneously active at resting membrane potential. When neurons were made to fire by passage of a brief $(10 \mathrm{msec})$ depolarizing current pulse through the recording electrode, the mean amplitude of the first evoked action potential was $93.0 \pm 2.0 \mathrm{mV}(n=31)$ and the duration was $1.8 \pm 0.1 \mathrm{msec}(n=31)$.

The typical responses of a BLA pyramidal cell to intracellular current injection and to electrical stimulation of afferents in the EC are shown in Figure 1 (left panels). When the cell was depolarized to a level just above spike threshold $(-56 \mathrm{mV})$ by delivery of a short (200 msec) $0.3 \mathrm{nA}$ current pulse, it fired a burst of two action potentials early in the depolarization and then fell silent for the duration of the pulse (Fig. 1 $A 1$, left). Delivery of a larger-amplitude depolarizing current pulse $(0.7$ nA) caused the cell to fire an initial burst of spikes followed by a short train of single action potentials at increasing interspike intervals that eventually gave way to complete accommodation in firing (Fig. 1 $A 1$, inset). The marked degree of spike frequency accommodation displayed by this cell can be seen in Figure $1 A 2$ (left), which illustrates the response obtained following intracellular injection of a $0.5 \mathrm{nA}$ depolarizing current pulse of more prolonged duration $(450 \mathrm{msec})$. In one-third of the pyramidal cells studied, the accommodation response was characterized by a complete cessation of discharge following an initial burst of action potentials, whereas in the remaining two-thirds it was 
Pyramidal

A
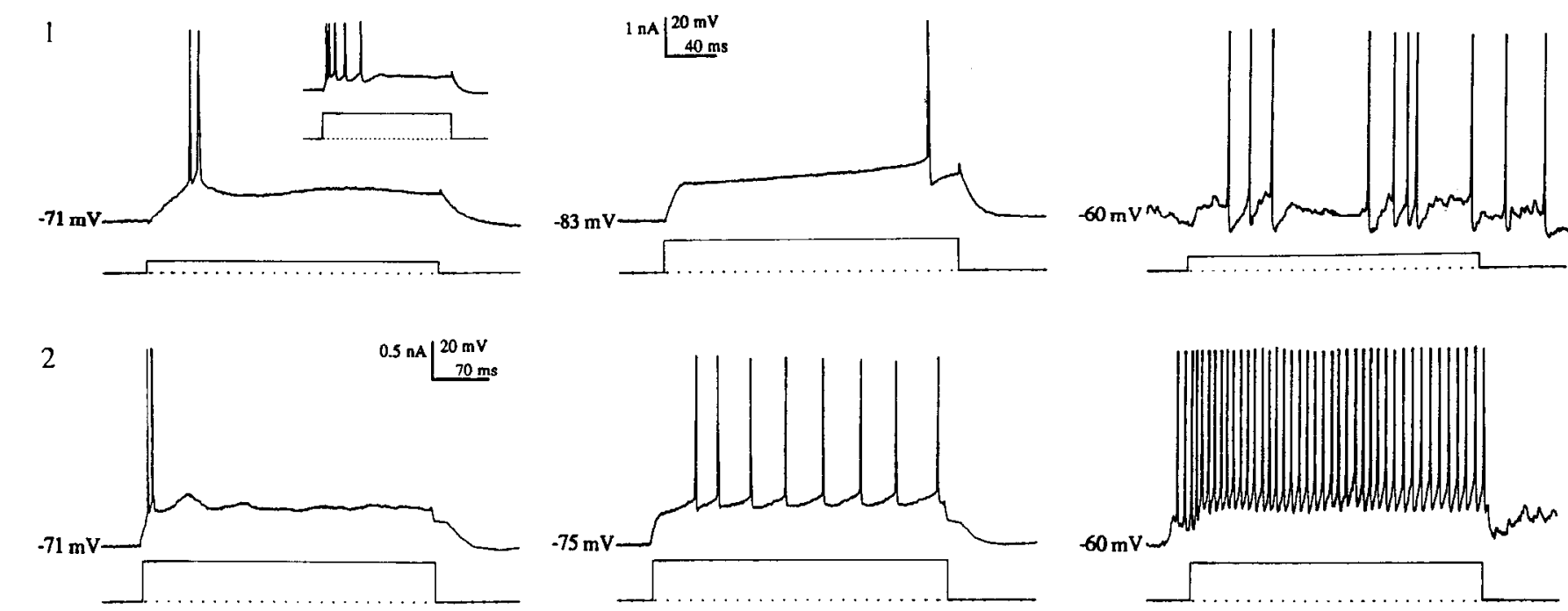

Fast-Firing

Late-Firing
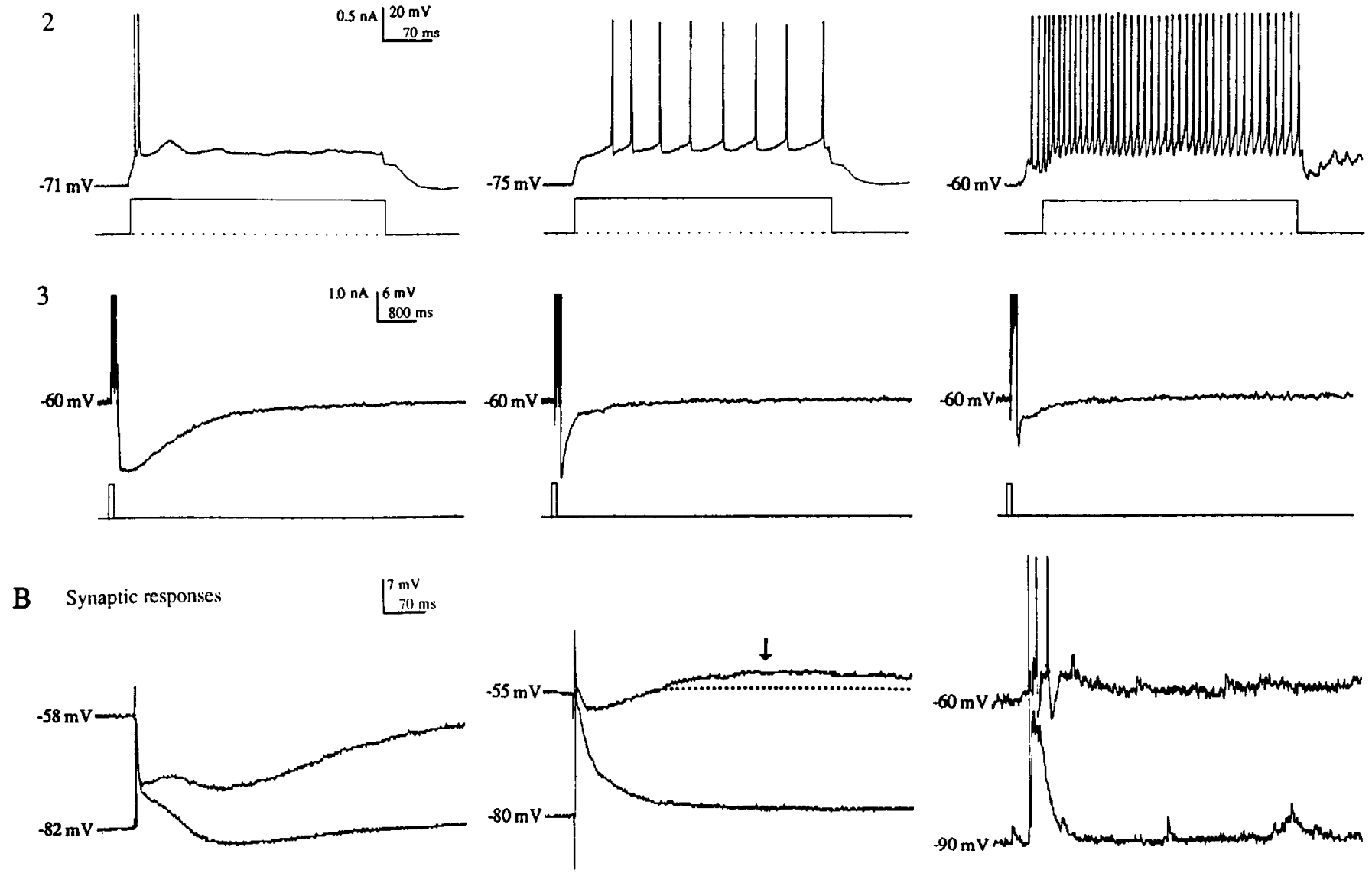

Figure 1. Comparison of current-evoked and synaptic responses of individual pyramidal, late-firing, and fast-firing rat BLA neurons. A1, Differences in threshold current-evoked responses. Left. The pyramidal cell generated a two-spike burst when depolarized to just above spike threshold by delivery of a $0.3 \mathrm{nA}$ current pulse and discharged a multispike burst to larger current injection $(0.7 \mathrm{nA}$; inset). Center and right, The response of a late-firing neuron to depolarization just above threshold consisted of a single action potential occurring late in the depolarization center, whereas the fast-firing neuron shown at the right discharged in bursts of action potentials throughout the duration of a depolarizing stimulus. In this and subsequent figures, the voltage records are displayed in the upper trace and the current steps in the lower trace. 2, Accommodation responses of BLA neurons. Left, Passage of a $450 \mathrm{mscc}$ depolarizing current pulsc $(0.5 \mathrm{nA})$ causcd the pyramidal ncuron to firc a burst of spikcs, after which it fell silent. Center, After an initial delay, the late-firing cell responded to the same stimulus by firing at a regular rate throughout most of the currentevoked depolarization. Note that this response was not elicited from resting membrane potential. Right, Identical stimulation parameters evoked a high-frequency spike discharge in the fast-firing neuron with no sign of accommodation. 3, AHPs of BLA neurons. Passage of a 1.0 nA shortduration (150 msec) current pulse through the recording electrode caused the pyramidal cell to fire a series of action potentials that was followed by a prolonged AHP (left). Delivery of an identical current pulse evoked actions potentials that were followed by transient AHPs in the late-firing (center) and the fast-firing cells (right). B. Synaptic responses to EC stimulation. Right, Responses of a pyramidal cell to EC stimulation (0.1 msec) recorded at membrane potentials depolarized $(-58 \mathrm{mV})$ and hyperpolarized $(-82 \mathrm{mV})$ from resting level. Center, Synaptically evoked responses of the late-firing neuron elicited from depolarized $(-55 \mathrm{mV})$ and hyperpolarized $(-80 \mathrm{mV})$ membrane potentials. Note the presence of a small IPSP and subsequent membrane depolarization (arrow) when the EC stimulation was delivered while recording at a membrane potential near firing threshold. Right, EC-evoked burst discharges of a fast-firing neuron from depolarized $(-60 \mathrm{mV})$ and hyperpolarized $(-90 \mathrm{mV})$ membrane potentials. Resting membrane potentials of the pyramidal, late-firing, and fast-firing neurons were $-71 \mathrm{mV},-83 \mathrm{mV}$, and $-60 \mathrm{mV}$, respectively. 
represented by a progressive slowing of spike discharge. Despite this difference in accommodation responses, virtually all pyramidal cells generated a prolonged afterhyperpolarization (AHP) of up to $20 \mathrm{mV}$ in amplitude after termination of a depolarizing current pulse that elicited a burst of action potentials $(1.0 \mathrm{nA}$, $150 \mathrm{msec}$ ) (Fig. 1A3). Although not readily apparent from the record shown in Figure $1 A 3$, the AHP evoked in BLA pyramidal cells was composed of an initial intermediate and subsequent slow component. Recordings from other neurons (Storm, 1989; Williamson and Alger, 1990) indicate that a variety of conductances, including $I_{\mathrm{M}}, I_{\mathrm{Q}}$, and $I_{\mathrm{C}}$, contribute to the intermediate AHP and that this conductance is thus distinguished from the fast AHP that follows single action potentials. The slow AHP is mediated by the activation of a calcium-dependent potassium conductance, termed $I_{\mathrm{AHP}}$ (Lancaster and Nicoll, 1987), which is distinct from the calcium-dependent potassium conductance underlying the fast AHP ( $I_{C}$; Lancaster and Adams, 1986; see also Washburn and Moises, 1992a,b).

Pyramidal-type neurons were also clearly identified as a homogeneous class of cells on the basis of the responses they gave to electrical stimulation of the EC. Figure $1 B$ (left) shows the profile of synaptic events typically recorded in a pyramidal neuron following EC stimulation with single shocks. When this cell was depolarized to just below spike threshold (upper trace) with direct current, stimulation of the EC elicited a short-latency EPSP of several millivolts in amplitude followed by a biphasic membrane hyperpolarization consisting of an early and late IPSP. As the cell was progressively hyperpolarized with constant current injection, the size of the $\mathrm{EC}$-evoked EPSP increased (lower trace). Work in this (Washburn and Moises, 1992b) and other laboratories (Rainine et al., 1991b) has demonstratcd that the early and late IPSPs evoked by stimulation of BLA afferents are mediated by the activation of $\mathrm{GABA}_{A}$ and $\mathrm{GABA}_{B}$ receptors, respectively, whereas the synaptically evoked EPSP is glutamatergic in nature (Rainine et al., 1991a). During recordings from pyramidal cells, spontaneous synaptic potentials were often seen as small positive or negative voltage deflections superimposed on the baseline resting membrane potential. Although spontaneous EPSPs were occasionally observed in recordings from pyramidal and nonpyramidal cell types, only pyramidal-type BLA neurons displayed spontaneous IPSPs.

\section{Late-firing neurons}

Stable, long-term impalements were obtained from 38 neurons that possessed a number of passive and active membrane properties that distinguished them from pyramidal and fast-firing neurons. A readily distinguishable feature of these neurons was the presence of a conspicuous delay in onset to firing to depolarizing stimuli, hence their designation as late-firing neurons. This class of neurons was also readily identified by their very negative resting membrane potential $($ mean $=-82.4 \pm 1.2 \mathrm{mV})$, which was significantly more negative than that of pyramidal $(-69.5 \pm 0.7 \mathrm{mV} ; p<0.05)$ or fast-firing neurons $(-62.0 \pm$ $2.2 \mathrm{mV} ; p<0.05)$. In addition, the average inpul resistance of late-firing neurons $(25.8 \pm 1.7 \mathrm{M} \Omega ; n=21)$ measured at resting membrane potential was markedly lower than that of pyramidal $(39.5 \pm 1.6 \mathrm{M} \Omega ; n=46)$ or fast-firing $(48.8 \pm 7.0 \mathrm{M} \Omega ; n=9)$ neurons. The duration and amplitude of the current-evoked action potential of late-firing $(1.5 \pm 0.1 \mathrm{msec} ; 98.0 \pm 1.6 \mathrm{mV}$; $n=22)$ and pyramidal cells $(1.5 \pm 0.1 \mathrm{msec} ; 93.0 \pm 2.0 \mathrm{mV}$; $n=31$ ) were not significantly different. The time constant of late-firing neurons averaged $7.3 \pm 0.5 \mathrm{msec}(n=21)$.
As noted above, late-firing neurons were classified and distinguished from pyramidal and fast-firing neurons based on the responses they gave to intracellular injections of depolarizing current. Delivery of a short $(200 \mathrm{msec})$ depolarizing current pulse produced a membrane depolarization having two distinct phases, an initial rapidly rising component followed by a gradual depolarization. When recording from a late-firing neuron at resting membrane potential, a single action potential was evoked at long delay from stimulus onset in response to a current stimulus that just exceeded threshold (Fig. 1 $A 1$, center). Delivery of a slightly smaller stimulus from a depolarized level $(-75 \mathrm{mV})$ evoked a train of action potentials that was initiated at a delayed onset latency (Fig. 1 $A 2$, center). Under these conditions, no accommodation of spike discharge was observed. In 33 of the 38 cells studied, an intermediate AHP was seen to follow the current-evoked train of action potentials (Fig. $1 A 3$, center). In contrast, only three late-firing cells showed the prominent slow AHP that was characteristic of pyramidal-type neurons.

The characteristic delay in current-evoked spike discharge that was found in all late-firing neurons might be accounted for by the activation of a fast potassium conductance that occurs upon depolarization of the membrane potential from rest. Likely candidates for producing these effects are $I_{\mathrm{A}}$ and $I_{\mathrm{D}}$, transient potassium currents that activate rapidly upon depolarization and inactivate during prolonged depolarization (Gustafsson et al., 1982; Rogawski, 1985; Storm, 1988, 1990; Surmeier et al., 1988). To investigate this possibility, we first examined the effect of conditioning membrane depolarization on the initial transient rectification of late-firing neurons. Cells were depolarized to a number of different potentials with direct current, and at each level a $20 \mathrm{msec}$ current pulse was delivered whose magnitude was adjusted $(0.1-0.9 \mathrm{nA})$ such that the neuron was depolarized to just above threshold for eliciting an action potential. Results from a typical experiment are shown in Figure $2 B$. In this neuron and all others tested $(n=9)$, the initial rectification was progressively attenuated as current-evoked responses were elicited from increasingly depolarized membrane potentials. The potential involvement of $I_{\mathrm{A}}$ or $I_{\mathrm{D}}$ in mediating the delay in spike firing was further examined in experiments in which we compared the responses of late-firing neurons $(n=4)$ to depolarizing current injection before and during superfusion of 4-AP. The results of a typical experiment are illustrated in Figure $2 C$. Addition of 4 -AP $(100 \mu \mathrm{M})$ to the bathing medium reversibly abolished the initial period of membrane rectification and allowed the initial phase of the electrotonic potential to reach a more depolarized level. As a result, late-firing neurons discharged spikes throughout the entire period of a current-evoked membrane depolarization in the presence of 4-AP (Fig. 2C, center). Similar results were obtained in all four neurons studied.

Synaptic responses to EC stimulation were examined in 35 late-firing neurons. The orthodromically evoked responses of a representative late-firing cell are shown in Figure $1 B$ (center). When recording from this cell at a membrane potential $(-80$ $\mathrm{mV}$ ) close to rest $(-83 \mathrm{mV})$, EC stimulation produced only a large EPSP (Fig. $1 B$, center). The amplitude of the EPSP decreased and was followed by a small IPSP $\left(E_{\mathrm{rev}}=-67.2+3.1\right.$ $\mathrm{mV} ; n=12$ ) and subsequent slow depolarization (Fig. $1 B$, center, arrow above upper trace) when EC stimulation was delivered while recording at a depolarized membrane potential $(-55 \mathrm{mV}$; Fig. $1 B$, center). This profile of synaptic responses was observed in 26 of 35 late-firing neurons when responses were recorded at membrane potentials near spike threshold $(-55$ to $-60 \mathrm{mV})$. 

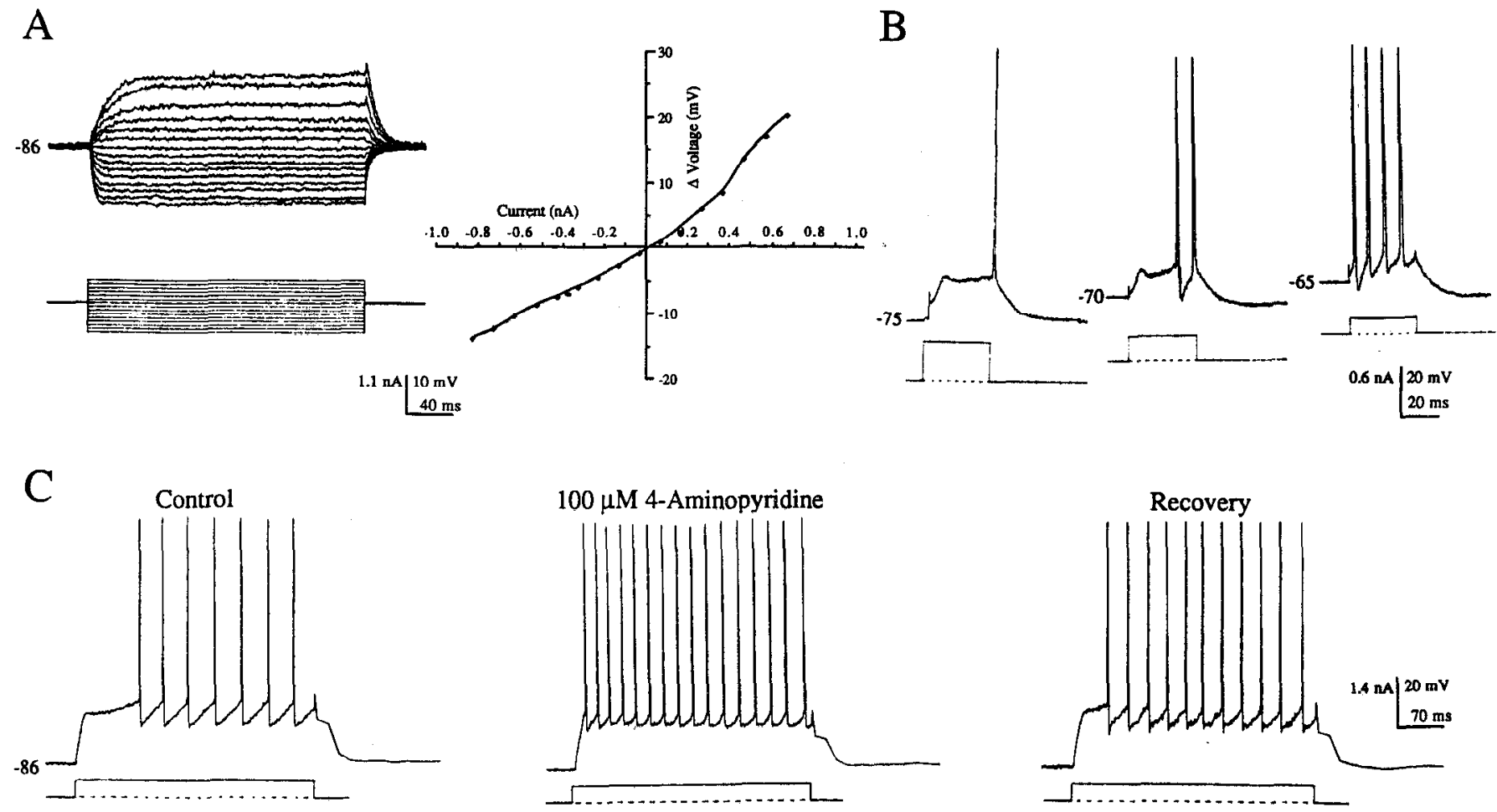

Figure 2. Membrane characteristics of a late-firing BLA neuron and reduction of membrane rectification by conditioning depolarization and 4AP. A: Left, Fifteen superimposed traces showing the electrotonic responses elicited by hyperpolarizing and depolarizing current pulses of varying magnitudes. Right. $I / V$ curve constructed from the maximum voltage deflections evoked by the series of current pulses in $A$. $B$, Patterns of action potential discharge evoked by a short $(40 \mathrm{msec})$ depolarizing current pulse delivered from three membrane potentials in the same late-firing cell as in $A$. In each instance, the amplitude of the current pulse $(0.6 \mathrm{nA}$ from $-75 \mathrm{mV}, 0.3 \mathrm{nA}$ from $-70 \mathrm{mV}, 0.2 \mathrm{nA}$ from $-65 \mathrm{mV})$ was adjusted such that the cell was depolarized to just above threshold for spike discharge. The membrane response to depolarizing current injection was characterized by an initial period of membrane rectification that was abolished as responses were elicited from progressively more depolarized membrane potentials. $C$, Records from the same cell as in $A$ and $B$ show blockade of membrane rectification during initial phase of a 350 msec, $0.5 \mathrm{nA}$ current pulse by $100 \mu \mathrm{M}$ 4-AP. Note that superfusion of 4-AP-containing medium also shortened the interspike interval. These effects were partially reversed 20 min after switching back to normal bathing medium. Resting membrane potential was $-86 \mathrm{mV}$.

In the remaining late-firing neurons, stimulation of the EC while recording at depolarized membrane potentials elicited only an EPSP $(n=2)$ or an EPSP followed by a slow depolarization $(n=1)$, an IPSP $(n=4)$, or an IPSP and subscquent late hyperpolarization $(n=2)$. The slow depolarization that followed the IPSP was only observed when recordings were obtained at membrane potentials depolarized quite far from the resting level. In many cases $(n=11)$, it was of sufficient amplitude to trigger one or two action potentials when EC stimulation was delivered during depolarization of the cell to near spike threshold. The finding that the slow depolarization increased in size as the cell was depolarized with direct current and was not elicited at resting membrane potential suggested that this depolarizing response was not a conventional EPSP mediated by release of a classical excitatory neurotransmitter.

\section{Fast-firing neurons}

A third population of cells, which we have referred to as fastfiring neurons, was encountered in less than $2 \%$ of all recordings from the rat BLA (10 of 689 total recordings). It was rather difficult to obtain stable, long-term impalements from these neurons, and in most instances the initial impalement resulted in rapid deterioration of the membrane properties of the cell. Thus, the low incidence of recordings that were obtained from fast-firing cells might be somewhat of an underestimate of the actual percentage of these neurons found in the BLA. The results discussed here were generated from 10 fast-firing cells in which we were able to obtain stable recordings for at least $20 \mathrm{~min}$.

Fast-firing neurons were often identified immediately upon impalcment by their high ratc of spontancous discharge (50$150 \mathrm{~Hz}$ ). Of the three cell classes described here, only fast-firing neurons were spontaneously active at resting membrane potential (6 of 10 cases). In addition, recordings obtained from 8 of the 10 fast-firing neurons showed a high constant rate (100-200 $\mathrm{Hz}$ ) of excitatory synaptic bombardment (for example, see records in Fig. 4B). A second characteristic by which fast-firing neurons were unambiguously distinguished from pyramidal and late-firing cells was by the short duration of their action potential $(0.7 \pm 0.1 \mathrm{msec} ; n=9$; range, $0.4-0.9 \mathrm{msec})$. The average resting membrane potential of fast-firing neurons $(-62.0 \pm 2.2 \mathrm{mV}$; range, -76 to $-56 \mathrm{mV} ; n=10$ ) was markedly more depolarized than that of the pyramidal or late-firing neurons. Although the apparent input resistance of fast-firing neurons was close to that of pyramidal cells (48.8 $\pm 7.5 \mathrm{M} \Omega$; range, 20.3-82.0 M 2 ) (Fig. $3 \mathrm{~A})$, the charging time constant of these cells $(5.8 \pm 0.7 \mathrm{msec}$; $n-9)$ was considerably faster than that of pyramidal cells (15.7 $\pm 0.7 \mathrm{msec}, n=41)$. In the majority of fast-firing cells $(n=7)$, the electrotonic potentials produced by injection of hyperpolarizing current pulses showed a small "sag," and a prominent depolarizing response followed the offset of the current pulse (see arrows in Fig. 3A).

Fast-firing neurons were also classified as constituting a dis- 
A
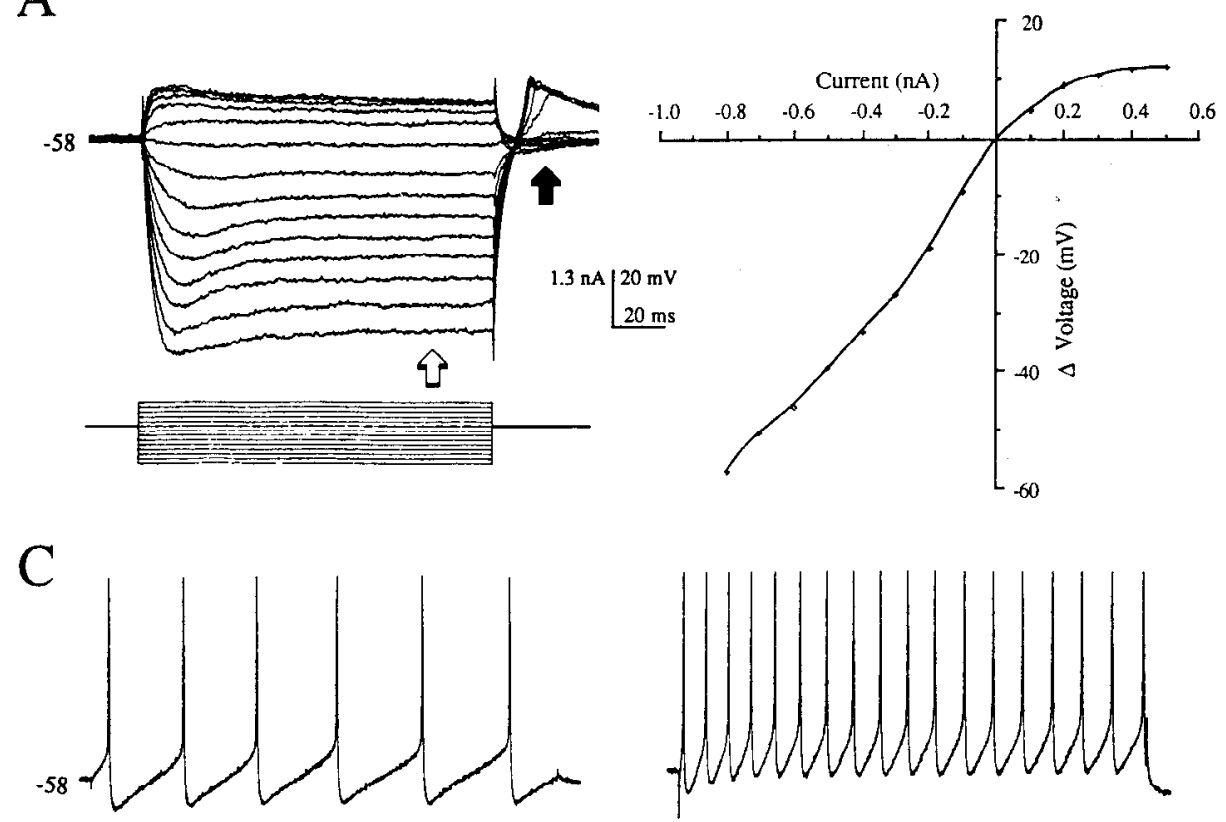

Ln+
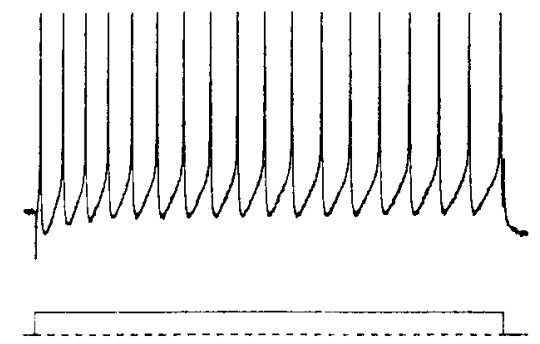

B
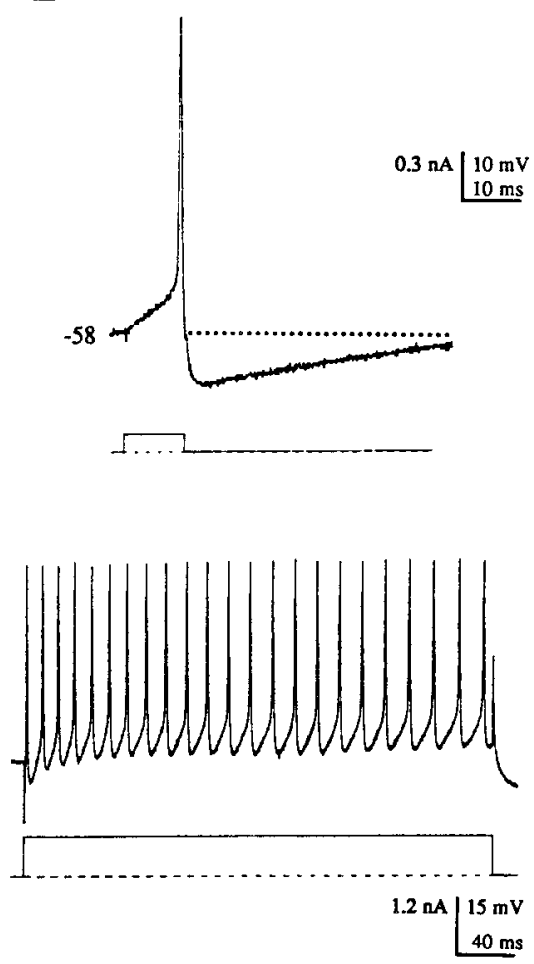

Figure 3. Membrane responses of a fast-firing BLA neuron to intracellular current injection. A: Left, Fourteen superimposed traces showing the electrotonic responses to a graded series of hyperpolarizing and depolarizing current pulses $(-0.8 \mathrm{nA}$ to $0.5 \mathrm{nA}, 150 \mathrm{msec})$. Responses wcre rccorded in the presence of $1 \mu \mathrm{M}$ TTX. Note the prominent sag in the hyperpolarizing electrotonic potential (open arrow) and the anode break excitation (solid arrow). Right, $I / V$ plot constructed from the maximum voltage deflections evoked by the series of current pulses illustrated in $A$. $B$, Passage of a $10 \mathrm{msec}$ depolarizing current pulse $(0.1 \mathrm{nA})$ evoked a single action potential that was followed by a prominent single spike AHP. Dotted line indicates resting membrane potential. $C$, Pattern of spike discharge produced in response to a 350 msec depolarizing current pulse of increasing amplitude (left to right). All records are from the same neuron. Resting membrane potential was $-58 \mathrm{mV}$.

tinct class of cells on the basis of their responses to intracellular injection of depolarizing current pulses. All 10 fast-firing cells fired trains of single action potentials at modest to high frequencies (100-200 Hz) in response to short and prolonged depolarizing current pulses, without signs of accommodation (Figs. 142 , right; $3 C$ ). However, while all fast-firing cells responded in a similar manner to a large-amplitude depolarizing current pulse, two rather distinct firing patterns were observed when cells were depolarized to a level just above threshold for spike firing. One group of fast-firing neurons $(n=4)$ fired several short bursts of action potentials separated by quiet periods throughout the duration of the depolarizing pulse (Fig. 1A1, right). The remaining six cells fired a continuous regularly spaced train of action potentials throughout the extent of the depolarizing stimulus at a rate that graded with the intensity of the current pulse (Fig. 3C). In all fast-firing cells, each individual action potential that was contained within the current-evoked spike train was followed by a pronounced fast AHP. Fast AHPs were also observed following single spikes that were evoked by intracellular injection of brief $(10 \mathrm{msec})$ small-amplitude current pulses (Fig. $3 B$ ). A longer-duration AHP was observed following a series of current-evoked action potentials, but this response was typically much smaller than those of pyramidal cells (Fig. 1A3, compare right and left).

The responses of fast-firing neurons to orthodromic activation following stimulation of the EC provided an additional means that helped to differentiate this class of cells from pyramidal and late-firing neurons. Whereas the synaptic response profile of pyramidal cells contained a prominent inhibitory component, the EC-evoked responses of fast-firing neurons consisted largely of excitatory events, as shown, for example, in Figure $1 B$ (right). In this neuron, stimulation of the EC with single shocks evoked an EPSP that was of sufficient amplitude to trigger a burst of action potentials when recording at resting membrane potential $(-60 \mathrm{mV})$. Note that no IPSP was observed following the ECevoked EPSP, which was characteristic of fast-firing neurons (six of nine cells tested). In three fast-firing cells, EC stimulation evoked an EPSP followed by either a small early IPSP ( $n=2$; Fig. $4 C,-56 \mathrm{mV}$ response) or an early and late $\operatorname{IPSP}(n=1)$.

As a group, fast-firing cells (six of nine) tended to fire in bursts or discharged a train of action potentials following EC stimulation, in contrast to pyramidal cells and late-firing neurons, which fired single spikes. However, two of the cells tested were somewhat unusual in that at most they could be made to fire only a single action potential even when high intensities of stimulation were used to drive BLA afferents within the EC (Fig. $4 C)$. The records in Figure $4 A$ show that both the duration of the orthodromically evoked bursts and the number of spikes per burst in fast-firing cells graded with changes in stimulus intensity. In this cell, a single action potential was evoked when the EC was stimulated at an intensity that was just above threshold for eliciting spike firing (Fig. $4 A$, left), whereas bursts consisting of two to five action potentials were evoked as the stimulus voltage was increased. The length of the burst was also dependent on the membrane potential of the cell at the time when recordings were being taken. This is illustrated in the 

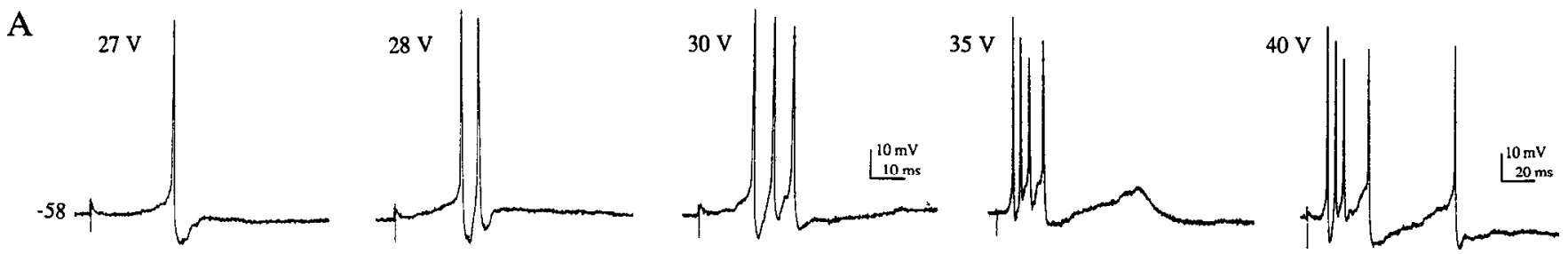

B
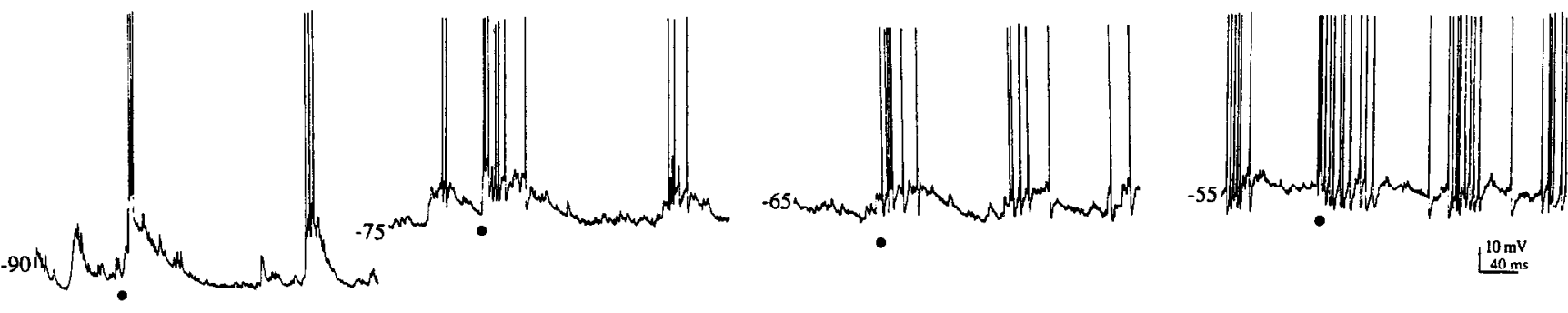

$\mathrm{C}$

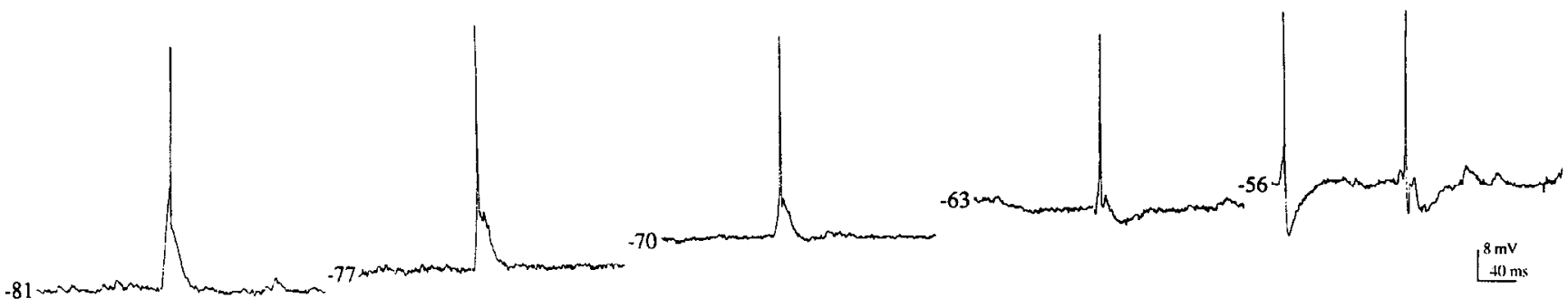

Figure 4. Effects of varying stimulus intensity or membranc potential on the synaptically cvoked responses of fast-firing BLA neurons to EC stimulation. $A$, This fast-firing neuron discharged a single action potential in response to stimulation of the EC with $0.1 \mathrm{msec}$ pulses at the threshold stimulus intensity $(27 \mathrm{~V})$ and with bursts of action potentials of increased duration as stimulus intensity was increased (left to right). B, Responses of a different fast-firing cell to EC stimulation recorded at various membrane potentials. Stimulation of the EC (solid circles below traces) while the membrane potential was manually clamped to $-90 \mathrm{mV}$ produced a large EPSP that led to the generation of a short burst of action potentials (left). As the membrane was depolarized by injection of DC current, EC stimulation with the same parameters evoked progressively longer trains of action potentials. $C$, Recording from a third fast-firing neuron that discharged single action potentials superimposed on an EPSP in response to EC stimulation, at all membrane potentials tested. Recordings obtained at resting membrane potential ( $-56 \mathrm{mV}, f a r$ right $)$ reveal a spontaneously generated single spike (first action potential in the record) that was followed an action potential generated in response to EC stimulation. Resting membrane potentials were $-58 \mathrm{mV}$ and $-61 \mathrm{mV}$ for the cells in $A$ and $B$, respectively.

records of Figure $4 B$, which shows EC-evoked responses that were recorded in another neuron while it was held at four different membrane potentials. At resting membrane potential ( -55 $\mathrm{mV})$, EC stimulation triggered a train of 12 action potentials in this neuron. Progressive hyperpolarization of the cell with direct current injection resulted in graded reductions in the number of action potentials per burst (Fig. $4 B$, right to left).

\section{Morphological characteristics of BLA neurons}

Seventy-eight neurons that had the physiological properties of pyramidal cells were successfully labeled intracellularly with $L Y$. Each of these neurons shared a common profile of morphological features like that shown in Figures 5 and 6 . The prominent features that enabled us to identify these neurons as pyramidal cells can be seen in Figure 5, which shows a photomicrograph and corresponding camera lucida reconstruction of an LY-labeled pyramidal cell. Cells bodies were usually pyramidal or conical in shape and measured from 10 to $30 \mu \mathrm{m}$ along their major axis. The somata of LY-labeled pyramidal cells were free of spines and had one to five gradually tapering apical dendrites that were estimated to be 3-5 $\mu \mathrm{m}$ thick. Typically, one of these dendrites was thicker than the rest and extended the farthest distance (200-700 $\mu \mathrm{m})$ from the soma. In the horizontal forebrain slice preparations used here, this major apical dendrite was often oriented in the rostral direction, although this ori- entation was less obvious in cells located along the medial or lateral borders of the nucleus. Each of the apical dendrites branched into 5-10 smaller secondary dendrites, which in many instances formed tertiary and, less often, quartenary branches. The initial branch point off of the major dendrite or dendrites usually occurred at a distance greater than $30 \mu \mathrm{M}$ from the cell body. Another morphological feature that was characteristic of pyramidal cells was the presence of dendritic spines. Although the soma and the proximal portions of the large-caliber dendrites were free of spines, all other portions of the dendrites were densely covered. These spines had thin stalks that ended in bulbous swellings, giving them a mushroom-like appearance (inset in Fig. 5).

In addition to the apical dendrite, pyramidal cells usually had five to nine thinner basal dendrites that emerged from the cell body. The basal dendrites usually arose from the base (Fig. 5) or, less often, from the side of the somata of pyramidal cells. These dendrites branched heavily within $100 \mu \mathrm{m}$ of the cell body, and the basal dendritic field generally did not extend more than $300 \mu \mathrm{m}$ from the soma. In most instances, the apical and basal dendrites extended away from the cell body in all directions, thus giving pyramidal cells a generally symmetrical appearance. The only exceptions to this were labeled neurons that were located along the lateral margin of the nucleus next to the EC. In these instances (see, e.g., Fig. 6A), the large majority of 


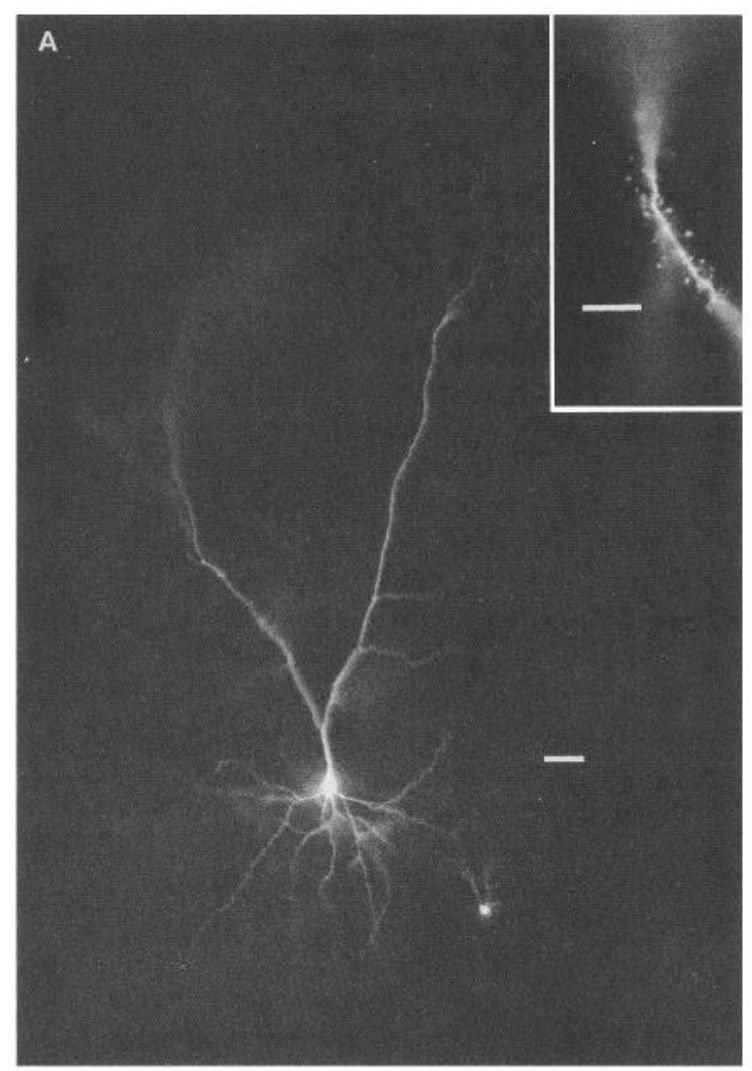

dendrites extended away from the EC whereas the axons were generally seen to enter it. Cells located in this position within the BLA had a definite asymmetrical appearance.

While the features described above were the general rule, pyramidal cell morphology formed something of a continuum. The six pyramidal cells shown in Figure 6 illustrate the transitional diversity of this class of neurons. Overall, we found that approximately $70 \%$ of the cells studied possessed a pyramidal soma and a prominent apical dendrite while approximately $30 \%$ of physiologically characterized pyramidal cells had stellate or multipolar somata and dendrites of roughly equal caliber and length. With the exception of the perikaryal shape and perceived lack of polarity, all morphological characteristics matched those of the pyramidal cells described above.

We were able to visualize major portions of the axonal systems of pyramidal cells only after long injection periods ( $>15 \mathrm{~min}$; $n=5$ ). In these neurons, a single labeled axon extended from the base or side of the cell body and gave rise to three to seven branches that formed an extensive axonal field (see Fig. 6). The principal axon and its collaterals were clearly distinguished from dendrites by their thinner diameter and lack of spines. In addition, numerous varicosities along the length of pyramidal cell axons often gave them a beaded appearance. The trajectory of the visualized axons was typically much straighter than that of the dendrites. Because of the large degree of axonal branching and fading of LY in the labeled axons during the course of observation, we were unable to delineate potential targets of the axons clearly. However, in four instances, axons were seen to enter and course through the EC.

Twelve neurons were labeled that possessed the electrophysiological characteristics of late-firing neurons. These cells displayed no preferred position or orientation within the BLA in horizontal slices. The characteristic morphological features of a late-firing cell are illustrated in Figure 7, which shows a photomicrograph and corresponding camera lucida drawing from a representative LY-labeled neuron. Figure 8 shows the diversity of morphologies found among neurons that exhibited electrophysiological properties of late-firing cells. This class of neurons was characterized by having pyramidal-like to ovoid cell bodies that measured 9-17 $\mu \mathrm{m}$ (mean, $13 \pm 0.5 \mu \mathrm{m}$ ) along their major axis. One to five primary dendrites and four to eight thinner dendrites radiated from the cell body in all directions. All dendrites branched profusely within $10-100 \mu \mathrm{m}$ of the cell body and formed a compact dendritic field that was typically much smaller and denser than that of the LY-labeled pyramidal cells. The dendritic branch points of late-firing cells appeared to be more closely spaced than in physiologically characterized and morphologically identified pyramidal neurons, and there appeared to be a relatively high incidence of tertiary and quartenary branching in late-firing neurons. These cells were also recognized as having a morphology distinct from pyramidal cells by virtue of the fact that the most prominent of the apical dendrites ended abruptly within 10-20 $\mu \mathrm{m}$ of the cell body and branched into two to four secondary dendrites from this same point. This was in marked contrast to the typical gradually tapering apical dendrite of pyramidal cells. Apical and basal dendrites of physiologically identified late-firing neurons were densely covered with pedunculated dendritic spines (Fig. 7, inset) that appeared to be indistinguishable from those of pyramidal cells, in terms of both their morphology and density of packing on the dendrites.

Axons were visible in only 3 of the 12 LY-labeled late-firing neurons. These arose from the base or side of the cell body and branched repeatedly in close proximity to the perikaryon as 


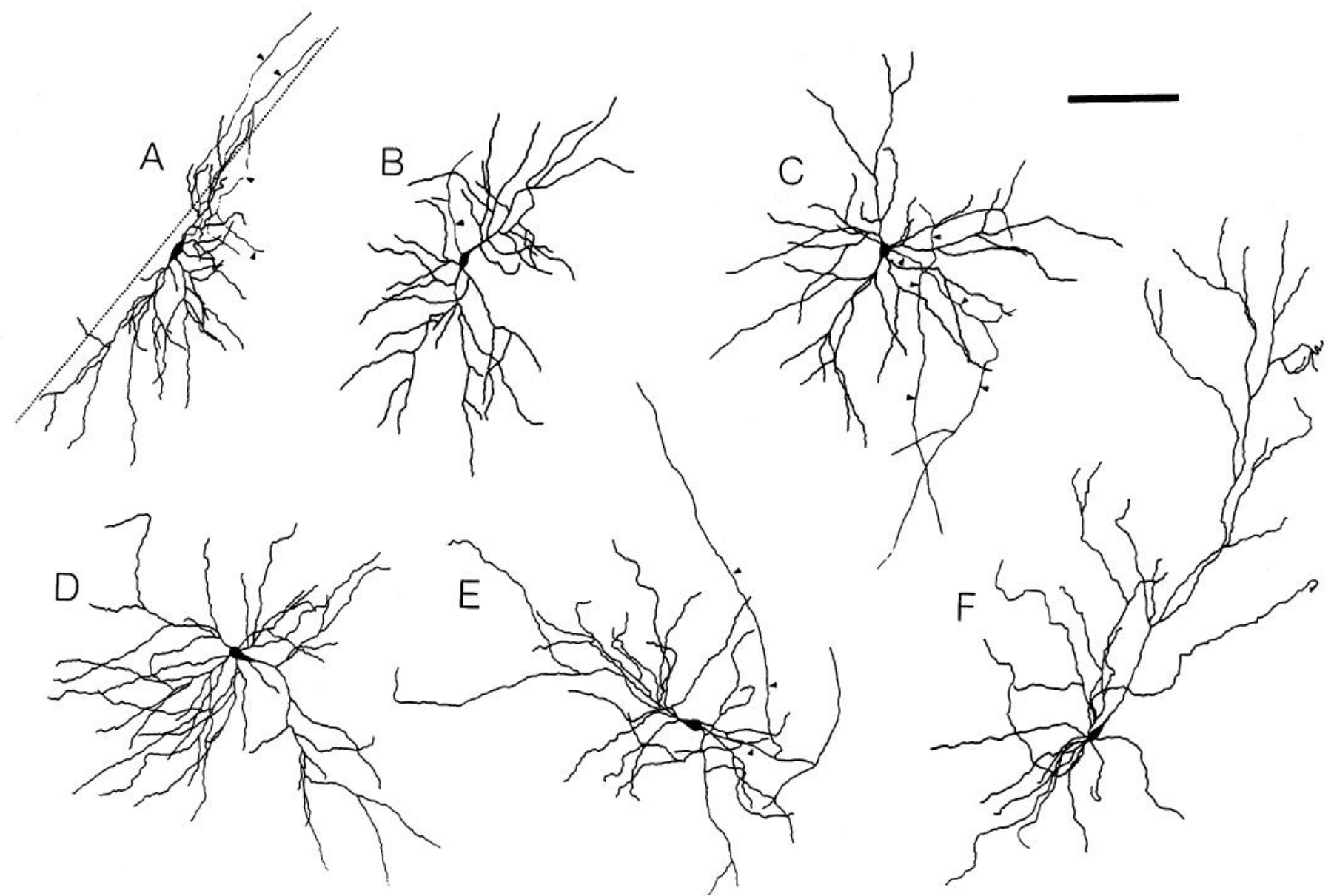

Figure 6. Camera lucida reconstructions of six electrophysiologically identified LY-filled pyramidal cells in rat BLA. A, Multipolar pyramidal neuron located at the lateral border of the BLA (dotted line indicates approximate border of the BLA with the EC). Note that while most of the dendrites of this neuron did not enter the EC, two axon collaterals (arrowheads) were seen to enter and course through this fiber pathway. B, Bipolar cell in rat BLA. Note the two apical dendrites radiating from opposite poles of the cell body. An axon extended from the side of the cell body (arrowhead). $C$, Multipolar neuron with extensively branching axon (arrowheads). $D-F$, Neurons with various dendritic morphologies and pyramidal somata. Note that the cells in $D$ and $F$ possessed apical dendrites that branched at considerable distances from the cell body, while that of the cell in $E$ branched close to the soma. Scale bar, $100 \mu \mathrm{m}$.

Figure 7. Morphology of a physiologically identified late-firing neuron in rat BLA. A, Fluorescence micrograph of an LY-labeled late-firing cell with a pyramidal-like cell body. Inset, Highermagnification micrograph of the dendrites of the cell in $A$ showing mushroom-like dendritic spines. $B$, Camera lucida reconstruction of the cell shown in $A$. Note the extensive amount of branching of the axon (arrowheads) and its collaterals (the thinner processes are not visible in the micrograph) in the region near the cell body. Scale bars: $A$ and $B, 20 \mu \mathrm{m}$; inset, $10 \mu \mathrm{m}$.
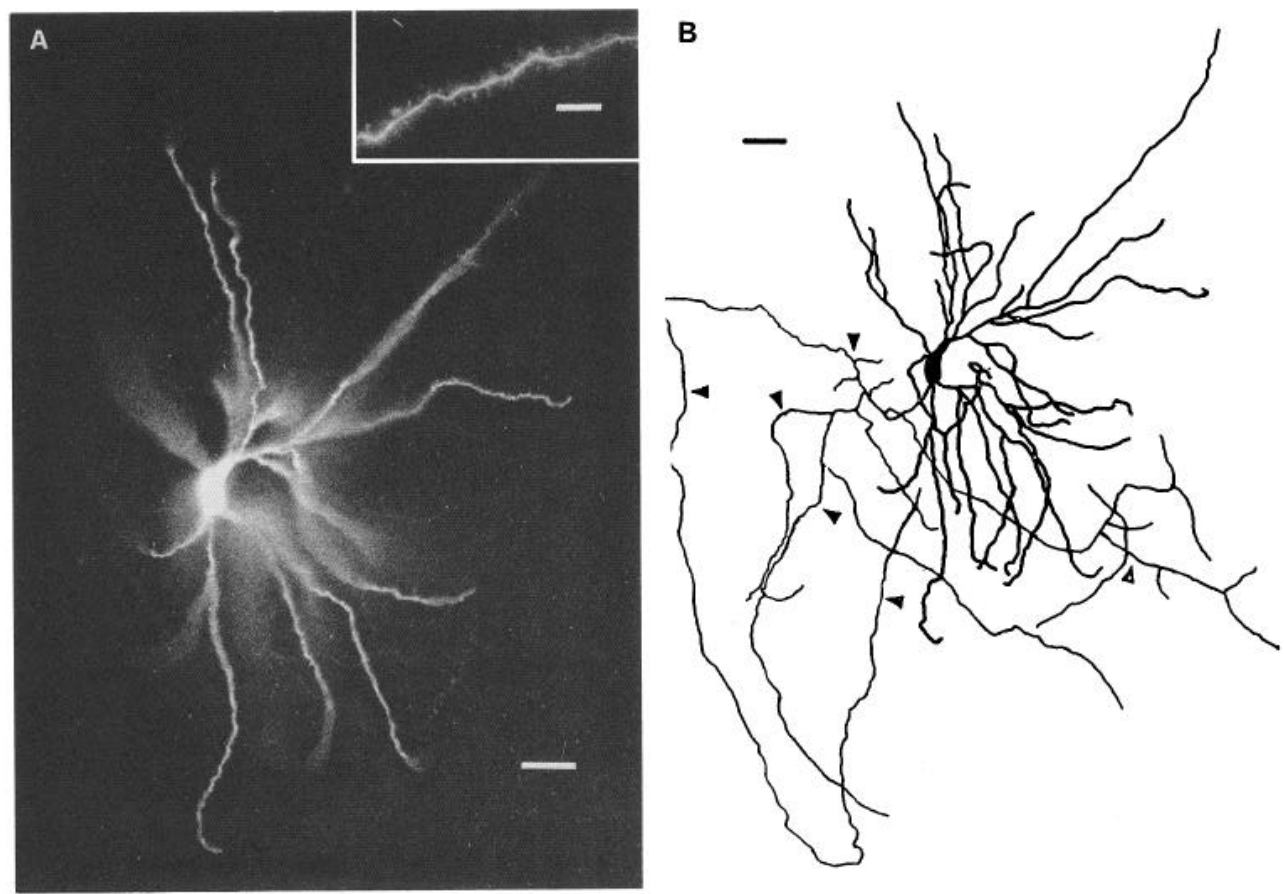

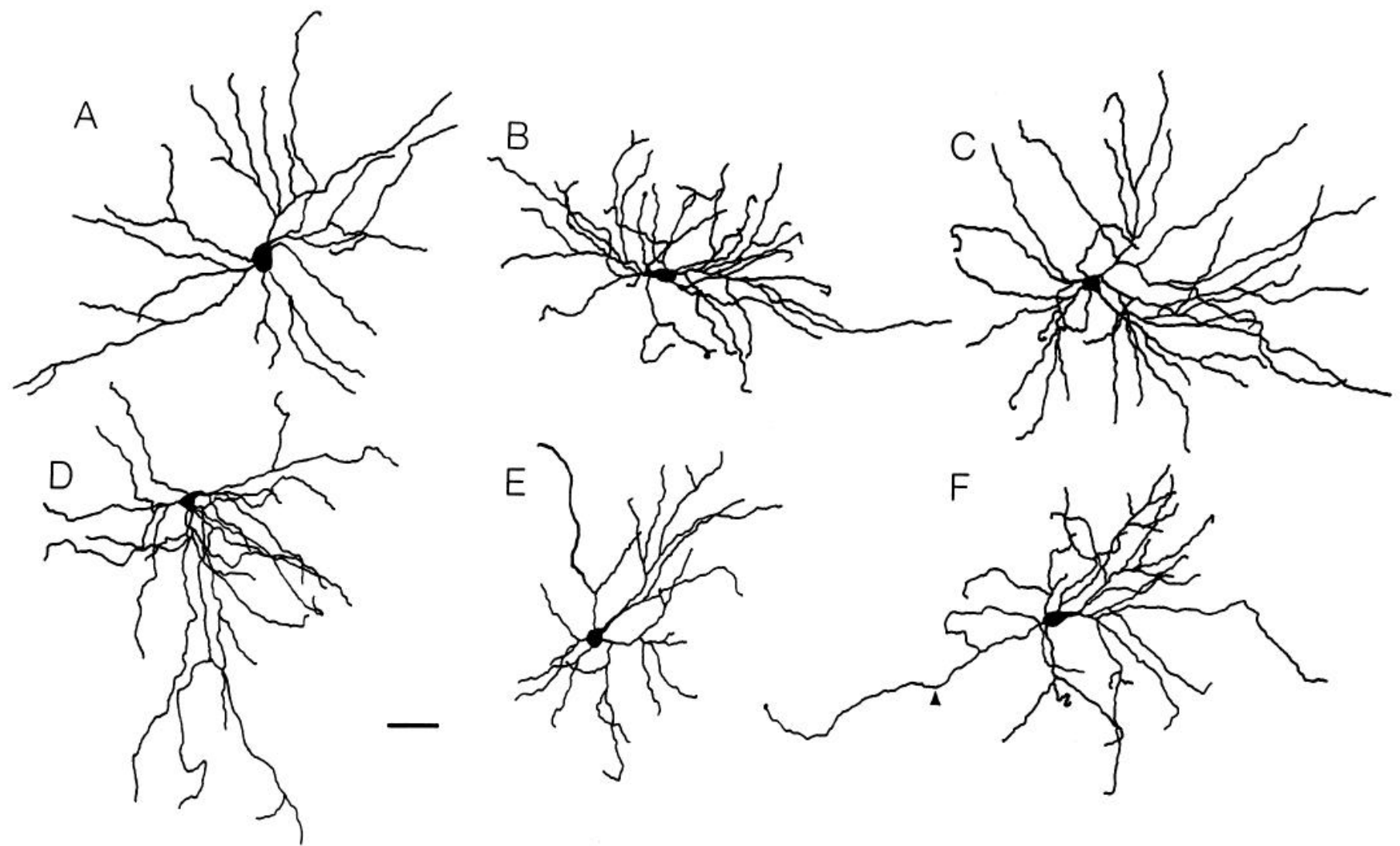

Figure 8. Camera lucida reconstructions of six electrophysiologically identified LY-labeled late-firing neurons in the rat BLA. A, Stellate cell with dendrites extending radially away from the cell body. $B$, Pyramidal-like cell with short dendrites. $C$ and $D$, Multipolar cells with compact dendritic fields. $E$ and $F$, Small pyramidal-like cells with prominent apical dendrites and thinner basal dendrites extending from sides and base of cell body. Arrowhead in $F$ indicates the axon that extended from the base of the soma. Scale bar, $20 \mu \mathrm{m}$.

illustrated for the cell shown in Figure 7 (arrowheads). The axon collaterals of the LY-filled late-firing cell, like those of the labeled pyramidal cells, were clearly distinguished from dendrites by their thinner diameter $(0.5-1 \mu \mathrm{m})$ and aspiny, varicose appearance.

Seven BLA neurons that possessed the electrophysiological characteristics of fast-firing neurons were recovered following intracellular labeling with LY. A photomicrograph and corre- sponding camera lucida reconstruction of a fast-firing neuron are shown in Figure 9, and camera lucida drawings of five others are shown in Figure 10. The size and shape of the somata of fast-firing neurons were found to be quite heterogeneous and ranged from fusiform or multipolar to spherical. These neurons had one to four primary dendrites that branched to a much smaller degree than those of pyramidal or late-firing neurons. In addition, the dendritic processes of these cells were aspiny
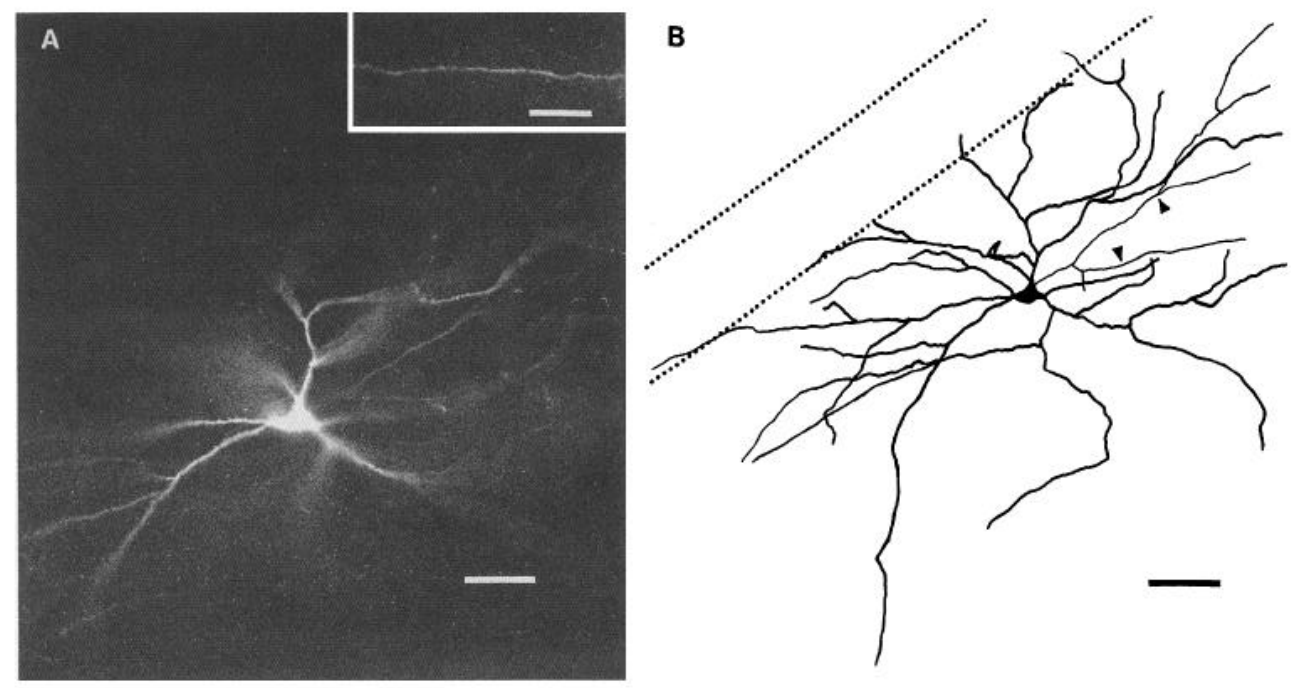

Figure 9. Morphology of a fast-firing neuron in the rat BLA. $A$, Fluorescence micrograph of an LY-filled spine-sparse multipolar neuron located adjacent to the EC. Inset, Higher-magnification micrograph shows the aspiny dendrites of the same cell. $B$, Camera lucida reconstruction of the same cell as in $A$. The approximate boundaries of the EC are shown by dotted lines. Note that dendrites of this neuron extended only a short distance into the EC. The axon (arrowheads) is visible as a very fine process extending from the cell body in a course roughly parallel to that of the EC. Scale bars: $A, 20 \mu \mathrm{m}$; inset, $14 \mu \mathrm{m}$; $B, 28 \mu \mathrm{m}$. 


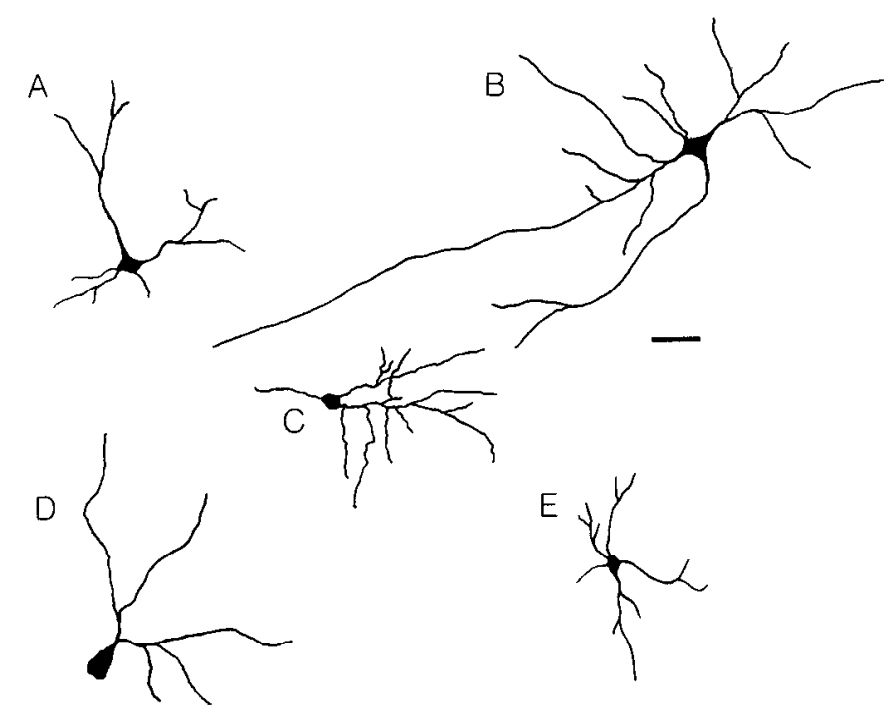

Figure 10. Camera lucida reconstructions of spineless or spine sparse fast-firing neurons in rat BLA. $A, B$, and $E$ show multipolar neurons whose dendrites extended in a radial fashion away from the cell body. No spines were observed on any of the dendrites of these neurons. Note the simple branching pattern of the neurons drawn here. $C$, Small fastfiring neuron with spherical cell body and spine-sparse dendrites. This is the same small cell shown to be adjacent to the larger LY-labeled pyramidal cell in the micrograph in Figure $5 A$. $D$, Tufted cell with conical cell body and simple dendritic pattern. Scale bar, $20 \mu \mathrm{m}$.

or spine sparse, a characteristic that further distinguished them from pyramidal cells and late-firing neurons (Fig. 9, inset). When dendritic spines were present, they were of the sessile rather than pedunculated type, and therefore appeared as small bumps rather than stalks with beads at their ends. A further distinguishing morphological feature of these cells was their dendritic fields, which were typically much smaller and simpler than those of the previously described cell classes. With the exception of the cell shown in Figure 9, we were unable to visualize any portion of the axons of fast-firing cells and therefore cannot comment on the overall extent of axonal branching of these neurons. It should be noted that because of the fragility of the impalements, the duration of dye-injection in these cells was generally limited to no more than $1 \mathrm{~min}$. Therefore, we cannot be certain that fast-firing cells were labeled as completely as pyramidal or late-firing cells. Nonetheless, it appeared that this potential limitation was partially overcome by the presumed smaller total volume of these cells since short LY injections could lead to fills like that of the fast-firing cell seen in Figure 9.

\section{Discussion}

In this study, we have demonstrated the presence of three distinct classes of neurons in the rat BLA that can be distinguished on the basis of their electrophysiological properties. In addition, each physiologically defined class of neurons was shown to correspond generally to a morphologically discrete category of cells as determined by intracellular labeling with LY. The predominant cell type was the pyramidal-type neuron, which accounted for approximately $93 \%$ of the total recordings obtained in rat BLA. Pyramidal cells were characterized electrophysiologically by their rapid discharge of a short burst of action potentials in response to short depolarizing current pulses and their prominent accommodation responses to prolonged depolarizing stimuli. Neurons in this class were also identified by the presence of a prolonged slow AHP that followed a series of currentevoked action potentials. A second class of cells was designated as late-firing neurons and accounted for most of the remaining $7 \%$ of impalements. These cells were clearly distinguished from pyramidal neurons by virtue of the fact that they fired action potentials at a delayed onset in response to intracellular injection of a depolarizing current pulse and by their very negative resting membrane potential. The third class of cells consisted of a small group of fast-firing neurons that possessed electrophysiological characteristics that were essentially indistinguishable from those of local intrinsic inhibitory interneurons found in hippocampus (Schwartzkroin and Mathers, 1978; Lacaille and Schwartzkroin, 1988a; Scharfman and Schwartzkroin, 1988) and cortex (McCormick et al., 1985). All 10 of these neurons fired trains of single action potentials at moderate to high frequencies in response to short and prolonged depolarizing current pulses, without evidence of accommodation. These cells were further distinguished by the short duration $(0.7 \pm 0.1 \mathrm{msec})$ of their action potentials.

\section{Pyramidal neurons}

The passive and active membrane properties of BLA pyramidal neurons recorded here are in close agreement with those described previously for pyramidal cells in this brain region (Gean and Shinnick-Gallagher, 1988, 1989; Washburn and Moises, 1992a,b; Womble and Moises, 1992). They are also remarkably similar to those of pyramidal cells in rat hippocampus (Wong and Prince, 1981; Madison and Nicoll, 1984) and cortex (Connors et al., 1982; McCormick et al., 1985; Changac-Amatai et al., 1990). This was particularly evident in regard to the responses produced in these cells by intracellular injection of depolarizing current. Thus, passage of a $250 \mathrm{msec}$ depolarizing current pulse triggered a burst of action potentials, followed by a marked accommodation response. In two-thirds of the pyramidal cells studied, the accommodation response was characterized by a progressive slowing of spike discharge, whereas in the remaining one-third it was represented by a complete cessation of discharge following an initial burst of action potentials. In virtually all pyramidal cells, a prolonged hyperpolarizing potential consisting of an initial intermediate AHP (Storm, 1989; Williamson and Alger, 1990) and subsequent slow AHP were seen to follow a current-evoked series of action potentials. Results from current- (Washburn and Moises, 1992a) and voltage-clamp (Womble and Moises, 1992) recordings from our laboratory suggest that the AHPs recorded in rat BLA neurons are similar to those found in hippocampal (Lancaster and Adams, 1986; Lancaster and Nicoll, 1987; Madison et al., 1987) and cortical (McCormick and Prince, 1986; Constanti and Sim, 1987) pyramidal cells.

Intracellular labeling of neurons that exhibited the physiological properties of pyramidal cells revealed that these cells had morphological characteristics that were nearly identical to those of pyramidal cells described in Golgi studies of rat BLA (McDonald, 1982, 1984; Millhouse and DeOlmos, 1983). McDonald (1982, 1984) categorized his Golgi-impregnated material from rat BLA into three classes of cells consisting of spiny pyramidal-type projection neurons (class I), spine-sparse local circuit neurons (class II), and neurogliaform cells (class III). In the present study, LY labeling of cells that were characterized electrophysiologically as pyramidal cells revealed that the predominant cell type in rat BLA is a generally homogeneous class of spiny neurons that possess a pyramidal- or conical-shaped 
cell body with one to five large apical dendrites and five to nine thinner basal dendrites. Such neurons accounted for approximately $70 \%$ of all labeled cells that showed pyramidal cell physiology. The largest of the apical dendrites was generally oriented in the rostral direction, confirming earlier observations that were made in horizontal sections of rat BLA with the Golgi technique (Millhouse and DeOlmos, 1983; McDonald, 1984). The remaining $30 \%$ of LY-labeled neurons that were physiologically characterized as pyramidal cells had stellate or multipolar cell bodies with three to six spiny dendrites of roughly equal diameter that arose from a number of points around the cell body. There was not always a clear distinction between pyramidal and stellate cells, with many cells displaying intermediate morphologies. Stellate pyramidal cells have been described in previous Golgi impregnation studies of the rat BLA by both McDonald (1982, 1984) and Millhouse and DeOlmos (1983).

On the basis of their morphology, most of the LY-labeled pyramidal-type neurons described here bore a remarkable resemblance to hippocampal and, especially, spiny pyramidal and stellate cells in cortex (Peters and Kara, 1985a,b). This same observation has also been made previously in Golgi-stained preparations of rat BLA (McDonald, 1982, 1984; Millhouse and DeOlmos, 1983). Nonetheless, whereas the cortex and hippocampus exhibit a very strict structural organization, Golgi staining of neurons in rat BLA has so far failed to reveal any degree of systematic organization of neuronal elements, except in the posterior portion of the nucleus where the apical dendrites of pyramidal cells are oriented perpendicularly to the dendrites of presumed interneurons (McDonald, 1984).

\section{Late-firing neurons}

The most striking electrophysiological characteristics of latefiring neurons were their very negative resting membrane potential $(-82.4 \pm 1.2 \mathrm{mV})$ and conspicuous delay in the onset of spike firing in response to depolarizing current injection. The finding that the delayed onset to firing in these cells was blocked by conditioning depolarization or by bath application of 4-AP suggests that the activation of the transient potassium current, $I_{\mathrm{A}}$ or $I_{\mathrm{D}}$ might be responsible for mediating this characteristic firing pattern. While these two currents are similar in many ways, $I_{\mathrm{D}}$ has a slower rate of inactivation than $I_{\mathrm{A}}$, is more sensitive to $4-\mathrm{AP}$, and has a slightly more negative threshold for activation and inactivation (for review, see Storm, 1990). Although we were unable with conventional voltage recordings to determine unequivocally which of these transient potassium currents is present in late-firing neurons, two pieces of data suggest that activation of $I_{\mathrm{D}}$ was primarily responsible for mediating the characteristic delay in spike initiation. First, the initial period of membrane rectification was blocked at relatively negative levels of conditioning depolarization. Second, 4-AP blocked the initial delay before spike discharge at a concentration $(100 \mu \mathrm{M})$ that was at least an order of magnitude lower than that required to block $I_{\mathrm{A}}$ in central neurons when recording under voltage clamp (1-5 mM) (Gustafsson et al., 1982; Storm et al., 1988; Surmeier et al., 1988). Moreover, in recent voltageclamp recordings from late-firing cells, we have identified a slowly decaying potassium conductance whose characteristics, including sensitivity to low concentrations of 4-AP $(50 \mu \mathrm{M})$, are similar to those of $I_{\mathrm{D}}$ described in hippocampal pyramidal cells (see Storm, 1988). It should be noted that superfusion of 4-AP also increased the frequency of repetitive spike discharges in response to depolarizing current injection. This effect has been observed in cultured hippocampal pyramidal neurons (Segal et al., 1984) as well as rat BLA pyramidal cells (Gean and ShinnickGallagher, 1989). Thus, based on the present results, it would appear that $I_{\mathrm{D}}$, and possibly $I_{\mathrm{A}}$, plays an important role in controlling the pattern of spike discharge in two classes of BLA neurons, the pyramidal and late-firing cells.

Intracellular labeling of late-firing neurons with LY revealed that while such cells exhibited a morphological pattern that in some ways resembled those of pyramidal cells, they also displayed unique morphological features that identified them as a distinct anatomical class. Thus, while the cell bodies of latefiring neurons were typically pyramidal or pyramidal-like in appearance, they were consistently smaller than those of the vast majority of pyramidal neurons. In addition, the most prominent of the apical dendrites extending from the cell body of LY-labeled late-firing cells ended abruptly with two to four spiny dendritic branches emanating from this point. In contrast, a gradual tapering of the apical dendrites was characteristically observed in the majority of LY-labeled neurons that possessed the physiological properties of pyramidal cells. Moreover, although the dendrites of late-firing neurons displayed a spiny appearance much like that of pyramidal cells, they were generally shorter and branched more profusely than those of a typical LY-labeled pyramidal neuron. According to the classifications advanced by McDonald $(1982,1984)$, the spiny latefiring neurons described here would correspond to a subset of class I or spiny-type projection neurons. However, when the anatomical and electrophysiological data are considered together, we feel that late-firing cells constitute a distinct class of cells rather than a subset of pyramidal cells.

\section{Fast-firing neurons}

Fast-firing neurons were readily distinguished from pyramidal and late-firing neurons on the basis of their active and passive membrane properties, most notably the very short duration of their action potentials $(0.7 \pm 0.1 \mathrm{msec})$ and their ability to fire at a rapid rate of discharge in response to intracellular injection of depolarizing current. Overall, the electrophysiological properties of the fast-firing cells that were recorded in rat BLA were rcmarkably similar to those of identified inhibitory interneurons in rat and guinea pig hippocampus (Schwartzkroin and Mathers, 1978; Knowles and Schwartzkroin, 1981; Ashwood et al., 1984; Lacaille and Schwartzkroin, 1988a; Scharfman and Schwartzkroin, 1988) and cortex (Satou et al., 1983; McCormick et al., 1985). While fast-firing cells displayed a marked degree of heterogeneity in terms of their passive membrane properties, as a group they had a higher input resistance and shorter time constant than pyramidal or late-firing cells. In addition, fast-firing cells were the only cells that under our recording conditions were spontaneously active at rest. Fast-firing cells were also rather unique in that the majority of these neurons fired in bursts of action potentials, both spontaneously and in response to EC stimulation. The excitatory synaptic responses that were elicited in fast-firing neurons following EC stimulation were generally not followed by prominent IPSPs, and in this way these neurons were reminiscent of latc-firing cclls rather than pyramidal cells. The fact that neurons within this class exhibited considerable variability in terms of spontaneous and stimulus-evoked synaptic events, as well as their firing pattern to threshold depolarizing stimuli, suggests that these neurons did not comprise a homogeneous population.

The morphology of fast-firing cells was substantially different 
than that of pyramidal and late-firing cells. The somata of fastfiring cells were not pyramidal but rather consisted of a heterogeneous distribution of morphologies that ranged from spherical to multipolar. In addition, LY-labeled fast-firing neurons were typically aspiny or sparsely spiny. In the only cell in which spines were observed, spines were sessile and were readily distinguished from the mushroom-like spines of pyramidal and latefiring cells. The dendrites of fast-firing cells were generally shorter and branched to a much smaller extent than those of the pyramidal and late-firing cells. On the basis of thesc fcatures, we suggest that the fast-firing neurons described in this study correspond to the Golgi-labeled class II cells of McDonald (1982, 1984 ) and the aspiny stellate cells of Millhouse and DeOlmos (1983). Since only a small number $(n=7)$ of fast-firing cells were successfully labeled in this study, some members of the heterogeneous assortment of class II cells described in these studies were not seen here, most notably the bipolar and bitufted cells of McDonald (1982). It should be noted that a marked similarity in morphology exists between the LY-labeled fastfiring neurons described here and GABA-containing neurons that have been described in immunohistochemical studies in rat BLA (McDonald, 1985b; McDonald and Pearson, 1989) and cortex (Ottersen and Storm-Mathisen, 1984; Seguela et al., 1984). Based on common electrophysiological and morphological properties, we conclude that the fast-firing neurons described here arc likcly to represent a population or populations of intrinsic inhibitory interneurons.

The application of sensitive immunohistochemical methods by several groups has demonstrated that different populations of nonpyramidal neurons in the rat BLA are immunoreactive for a number of peptides including somatostatin, cholecystokinin, and vasoactive intestinal peptide (Roberts et al., 1982; McDonald, 1985a). McDonald (1985a) reported that there was a significant difference in perikaryal size among each of the different types of peptide-immunoreactive neurons. Recently, McDonald and Pearson (1989) showed further that most of these nonpyramidal peptide-containing neurons in rat BLA colocalized GABA. It is tempting to speculate that this diversity in neurochemical identity might in turn be related to the electrophysiological and morphological heterogeneity of fast-firing neurons described here and be reflected in the range of morphologics of Golgi-impregnated class II ncurons (McDonald, 1982, 1984; Millhouse and DeOlmos, 1983) and GABA-immunoreactive cells in rat BLA (McDonald, 1985b). This notion is especially appealing given that recent electrophysiological studies suggest that separate subclasses of inhibitory interneurons may underlie the early and late IPSPs recorded in neurons in the basolateral (Rainine et al., 1991) and lateral (Sugita et al., 1992) amygdala, as well as in hippocampal pyramidal cells (Lacaille et al., 1987; Lacaille and Schwartzkroin, 1988b; Segal, 1990; Doze et al., 1991).

In summary, we were able to identify three distinct cell types within the rat BLA based upon correlations of their electrophysiological properties and their morphological features as determined by LY labeling. Consistent with previous work (McDonald, 1982, 1984; Millhouse and DeOlmos, 1983; Washburn and Moises, 1992a), we found that the predominant cell type in this brain region consistcd of pyramidal neurons whosc electrophysiological and morphological properties are similar to those of pyramidal cells found elsewhere in the CNS. A somewhat unexpected finding was the identification of a previously uncharacterized cell type, designated here as late-firing neurons, whose morphological features were similar to those of pyramidal cells and that therefore may not have been identified as a distinct cell class in earlier Golgi studies. Finally, fast-firing neurons exhibited a profile of electrophysiological and morphological properties characteristic of GABAergic inhibitory interneurons. Taken together, these results support the notion that the BLA exhibits a neuronal organization that in many ways parallels that of cortex and hippocampus, brain regions with which the BLA maintains extensive interconnections (Carlsen and $\mathrm{Hei}-$ mer, 1988; Carlsen, 1989).

\section{References}

Ashwood TJ, Lancaster B, Wheal HV (1984) In vivo and in vitro studies on putative interneurons in the rat hippocampus: possible mediators of fecd-forward inhibition. Brain Res 293:279-291.

Carlsen J (1988) Immunocytochemical localization of glutamate decarboxylase in the rat basolateral amygdaloid nucleus, with special reference to GABAergic innervation of amygdalostriatal projection neurons. J Comp Neurol 273:513-526.

Carlsen J (1989) New perspectives on the functional anatomical organization of the basolateral amygdala. Acta Neurol Scand [Suppl] 122:1-27.

Carlsen J, Heimer L (1988) The basolateral amygdaloid complex as a cortical-like structure. Brain Res 441:377-380.

Changac-Amatai Y, Luhmann HJ, Prince DA (1990) Burst generating and regular spiking layer 5 pyramidal neurons of rat neocortex have different morphological features. J Comp Neurol 296:598-613.

Connors BW, Gutnick JA, Prince DA (1982) Electrophysiological properties of neocortical neurons in vitro. J Neurophysiol 48:13021320.

Constanti A, Sim JA (1987) Calcium-dependent potassium conductance in guinea-pig olfactory cortex neurons in vitro. J Physiol (Lond) 387:173-194.

Doze VA, Cohen CA, Madison DV (1991) Synaptic localization of adrenergic disinhibition in the rat hippocampus. Neuron 6:889-900.

Gean PW, Shinnick-Gallagher P (1988) Characterization of the epileptiform activity induced by magnesium-free solution in rat amygdala slices: an intracellular study. Exp Neurol 101:248-255.

Gean PW, Shinnick-Gallagher P (1989) The transient potassium current, the A-current, is involved in spike frequency adaptation in rat amygdala neurons. Brain Res 480:160-169.

Gustafsson B, Galvan M, Grafe P, Wigstrom H (1982) A transient outward current in a mammalian central neurone blocked by 4 -aminopyridine. Nature 299:252-254.

Knowles WD, Schwartzkroin PA (1981) Local circuit synaptic interactions in hippocampal brain slices. J Neurosci 1:318-322.

Lacaille J-C, Schwartzkroin PA (1988a) Stratum lacunosum-moleculare interneurons of hippocampal CA1 region. I. Intracellular response characteristics, synaptic responses, and morphology. J Neurosci 8:1400-1410.

Lacaille J-C, Schwartzkroin PA (1988b) Stratum lacunosum-moleculare interneurons of hippocampal CAl region. II. Intrasomatic and intradendritic recordings of local circuit synaptic interactions. J Neurosci $8: 1411-1424$.

Lacaille J-C, Mueller AL, Kunkel DD, Schwartzkroin PA (1987) Local circuit interactions between oriens/alveus interneurons and CA1 pyramidal cells in hippocampal slices. J Neurosci 7:1979-1993.

Lancaster B, Adams PR (1986) Calcium-dependent current generating the afterhyperpolarization of hippocampal neurons. J Neurophysiol 55:1268-1282.

Lancaster B, Nicoll RA (1987) Properties of two calcium-activated hyperpolarizations in rat hippocampal neurons. J Physiol (Lond) 389: 187-203.

Llinás RR (1988) The intrinsic electrophysiological properties of mammalian neurons: insights into central nervous system function. Science 242:1654-1664.

Madison DV, Nicoll RA (1984) Control of the repetitive discharge of rat CA 1 pyramidal neurons in vitro. J Physiol (Lond) 354:319-331.

Madison DV, Lancaster B, Nicoll RA (1987) Voltage clamp analysis of cholinergic action in the hippocampus. J Neurosci 7:733-741.

McCormick DA, Prince DA (1986) Mechanisms of action of acetylcholine in the guinea-pig cerebral cortex in vitro. J Physiol (Lond) 375:169-194. 
McCormick DA, Connors BW, Lighthall JW, Prince DA (1985) Comparative electrophysiology of pyramidal and sparsely spiny stellate neurons of the neocortex. J Neurophysiol 54:782-806.

McDonald AJ (1982) Neurons of the lateral and basolateral amygdaloid nuclei: a Golgi study in the rat. J Comp Neurol 212:293-312.

McDonald AJ (1984) Neuronal organization of the lateral and basolateral amygdaloid nuclei in the rat. J Comp Neurol 222:589-606.

McDonald AJ (1985a) Morphology of peptide-containing neurons in the rat basolateral amygdaloid nucleus. Brain Res 338:186-191.

McDonald AJ (1985b) Immunohistochemical identification of gamma-aminobutyric acid-containing neurons in the rat basolateral amygdala. Neurosci Lett 53:203-207.

McDonald AJ, Pearson JC (1989) Coexistence of GABA and peptide immunoreactivity in non-pyramidal neurons of the basolateral amygdala. Neurosci Lett 100:53-58.

Millhouse OE, DeOlmos J (1983) Neuronal configurations in lateral and basolateral amygdala. Neuroscience 10:1269-1300.

Moises HC, Washburn MS (1989) Pharmacology of inhibitory responses recorded in basolateral and lateral amygdaloid neurons in vitro. Soc Neurosci Abstr 15:525.

Ottersen OP, Storm-Mathisen J (1984) Glutamate- and GABA-containing neurons in the mouse and rat brain, as demonstrated with a new immunocytochemical technique. J Comp Neurol 229:374-392.

Paxinos $G$, Watson $C$ (1982) The rat brain in stereotaxic coordinates. Sydney: Academic.

Peters A, Kara DA (1985a) The neuronal composition of area 17 of rat visual cortex. I. The pyramidal cells. J Comp Neurol 234:218241.

Peters A, Kara DA (1985b) The neuronal composition of area 17 of rat visual cortex. II. The nonpyramidal cells. J Comp Neurol 234: 242-263.

Rainine DG, $\Lambda$ sprodini EK, Shinnick-Gallagher P (1991a) Excitatory transmission in the basolateral amygdala. J Neurophysiol 66:986998.

Rainine DG, Asprodini EK, Shinnick-Gallagher P (1991b) Inhibitory transmission in the basolateral amygdala. J Neurophysiol 66:9991009.

Roberts GW, Woodhams PL, Polak JM, Crow TJ (1982) Distribution of neuropeptides in the limbic system of the rat: the amygdaloid complex. Neuroscience 7:99-131.

Rogawski M (1985) The A-current: how ubiquitous a feature of excitable cells is it? Trends Neurosci 8:214-219.

Satou M, Mori K, Tazawa Y, Takagi SF (1983) Interneurons mediating fast postsynaptic inhibition in pyriform cortex of the rabbit. Neurophysiology 50:89-101.
Scharfman HE, Schwartzkroin PA (1988) Electrophysiology of morphologically identified mossy cells recorded in guinea pig hippocampal slices. J Neurosci 8:3812-3821.

Schwartzkroin PA, Mathers I.H (1978) Physiological and morphological identification of a nonpyramidal hippocampal cell type. Brain Res 157:1-10.

Segal M (1990) A subset of local interneurons generate slow inhibitory postsynaptic potentials in hippocampal neurons. Brain Res 511:163164.

Segal M, Rogawski MA, Barker JL (1984) A transient potassium conductance regulates the excitability of cultured hippocampal and spinal neurons. J Neurosci 4:604-609.

Seguela P, Geffard M, Buijs RM, Le Moal M (1984) Antibodies against gamma-aminobutyric acid: specificity studies and immunocytochemical results. Proc Natl Acad Sci USA 81:3888-3892.

Storm JF (1988) Temporal integration by a slowly inactivating $\mathrm{K}^{+}$ current in hippocampal neurones. Nature 336:379-381.

Storm JF (1989) An after-hyperpolarization of medium duration in rat hippocampal pyramidal cells. J Physiol (Lond) 409:171-190.

Storm JF (1990) Potassium currents in hippocampal pyramidal cells. Prog Brain Res 83:161-187.

Sugita S, Johnson SW, North RA (1992) Synaptic inputs to GABA and $\mathrm{GABA}_{\mathrm{B}}$ receptors originate from discrete afferent neurons. Neurosci Lett 134:207-211.

Surmeier DJ, Bargas J, Kitai ST (1988) Voltage-clamp analysis of a transient potassium current in rat neostriatal neurons. Brain Res 473: $187-192$.

Washburn MS, Moises HC (1990) Muscarinic responses of cellular subtypes in rat basolateral amygdala in vitro. Soc Neurosci Abstr 16: 62.

Washburn MS, Moises HC (1992a) Muscarinic responses of rat basolateral amygdaloid neurons recorded in vitro. J Physiol (Lond) 449: 121-154.

Washburn MS, Moises HC (1992b) Inhibitory responses of rat basolateral amygdaloid neurons recorded in vitro. Neuroscience, in press.

Williamson A, Alger BE (1990) Characterization of an early AHP after a brief train of action potentials in rat hippocampal neurons in vitro. J Neurophysiol 63:72-81.

Womble MD, Moises HC (1992) Voltage-clamp analysis of cholinergic action in the basolateral amygdala. J Physiol (Lond), in press.

Wong RK, Prince DA (1981) Afterpotential generation in hippocampal pyramidal cells. J Neurophysiol 45:86-97. 